Review

\title{
Impact of Hepatitis B Virus Genetic Variation, Integration, and Lymphotropism in Antiviral Treatment and Oncogenesis
}

\author{
Keith C.K. Lau ${ }^{1,2}$, Kelly W. Burak ${ }^{2}(\mathbb{D})$ and Carla S. Coffin $1,2, * \mathbb{( D}$ \\ 1 Department of Microbiology, Immunology and Infectious Diseases, Cumming School of Medicine, \\ University of Calgary, Calgary, AB T2N 1N4, Canada; kcklau@ucalgary.ca \\ 2 Calgary Liver Unit, Division of Gastroenterology and Hepatology, Department of Medicine, \\ Cumming School of Medicine, University of Calgary, Calgary, AB T2N 1N4, Canada; kwburak@ucalgary.ca \\ * Correspondence: cscoffin@ucalgary.ca; Tel.: +1-(403)-592-5049
}

Received: 26 August 2020; Accepted: 22 September 2020; Published: 24 September 2020

\begin{abstract}
Chronic Hepatitis B Virus (HBV) infection poses a significant global health burden. Although, effective treatment and vaccinations against HBV are available, challenges still exist, particularly in the development of curative therapies. The dynamic nature and unique features of HBV such as viral variants, integration of HBV DNA into host chromosomes, and extrahepatic reservoirs are considerations towards understanding the virus biology and developing improved anti-HBV treatments. In this review, we highlight the importance of these viral characteristics in the context of treatment and oncogenesis. Viral genotype and genetic variants can serve as important predictive factors for therapeutic response and outcomes in addition to oncogenic risk. HBV integration, particularly in coding genes, is implicated in the development of hepatocellular carcinoma. Furthermore, we will discuss emerging research that has identified various HBV nucleic acids and infection markers within extrahepatic sites (lymphoid cells). Intriguingly, the presence of hepatocellular carcinoma (HCC)-associated HBV variants and viral integration within the lymphoid cells may contribute towards the development of extrahepatic malignancies. Improved understanding of these HBV characteristics will enhance the development of a cure for chronic HBV infection.
\end{abstract}

Keywords: HBV; genetic variation; integration; treatment; oncogenesis; HCC; lymphotropism

\section{Introduction}

The Hepatitis B Virus (HBV) is a significant global viral pathogen. An estimated two billion individuals worldwide have been exposed to the virus with approximately 257 million living with chronic HBV infection (CHB) [1]. HBV is responsible for over 800,000 deaths a year primarily due to the induction of hepatocellular carcinoma (HCC), cirrhosis, and acute hepatitis [2]. The introduction of the HBV vaccine consisting of recombinant HBV surface antigen (HBsAg) has effectively reduced the spread of HBV, particularly in young children [1]. However, HBV remains endemic in many areas of the Southeast Asia region and Africa, which have an estimated prevalence of $6.2 \%$ and $6.1 \%$, respectively [1,3]. Within Canada, there are an estimated 260,000 chronically infected individuals ( $0.76 \%$ estimated prevalence), with the majority of those with $\mathrm{CHB}$ are new Canadians from endemic areas [3,4]. Within the Calgary Health Zone in Alberta, Canada, our prior research study reported a total of 1214 individuals ( $0.10 \%$ of population within Calgary zone) who tested positive for HBsAg within a single calendar year (2014) [4]. The majority of these cases are likely newly diagnosed CHB carriers, many of which lacked appropriate monitoring and management of their disease. $\mathrm{CHB}$ represents a significant disease burden worldwide, and will require substantial investment in prevention, research, 
and patient care to achieve the World Health Organization (WHO) goals for elimination of viral hepatitis by 2030 .

The HBV is transmitted both horizontally and vertically into new human hosts. Horizontal transmission may occur through exposure to materials, such as blood or semen containing infectious HBV particles. However, horizontal transmission into adult immunocompetent hosts most frequently develops into a self-limiting acute infection with clearance of HBsAg and development of HBsAg antibodies (anti-HBs). CHB is defined by positive HBsAg in serum for greater than 6 months duration. The vast majority of $\mathrm{CHB}$ carriers are infected by transmission of the virus by mother-to-child transmission during childbirth or close contact with blood and body fluids of other family members in early childhood (i.e., $<5$ years of age) [5]. In contrast, only $5 \%$ or less of adolescents and adults who are exposed to HBV eventually progress to CHB infection [6]. Individuals persistently infected with $\mathrm{HBV}$ are at risk of development of severe liver complications including cirrhosis and primary liver cancer (HCC).

In this review, we will briefly discuss the natural history of $\mathrm{CHB}$ and the two main categories of therapeutics for CHB management (interferon and nucleos/tide analogues). It is noteworthy that persistent HBV infection has unique viral aspects, which affect antiviral treatment choices as well as oncogenic risk. These viral features include HBV genotype/genetic variations, integration of HBV DNA into host chromosomes, and recent data suggesting role of viral lymphotropism. In addition, HBV genetic variants, integration, and lymphotropism will be discussed as a consideration in the development of new antiviral therapeutics.

\subsection{Natural History of Chronic HBV Infection}

The natural history of CHB infection is complex and has been divided into distinct phases [7-9]. An important viral marker utilized in the classification of $\mathrm{CHB}$ phases is presence or absence of viral hepatitis B " $\mathrm{e}$ " antigen (HBeAg). The secreted non-structural HBeAg is a non-essential secreted protein with regards to the viral replicative life cycle and has significant sequence homology to the viral HBV core (capsid) protein $[7,10]$. Indeed, $\mathrm{HBeAg}$ is an immunomodulator that has been shown to inhibit both innate and adaptive immunity through a variety of mechanisms such as interfering with interferon expression and induction of T-cell exhaustion [7,11]. The first phase is defined as a high replicative and low inflammatory "HBeAg positive infection" (Figure 1). Typically, CHB carriers in this phase are characterized with extremely high viral load (i.e., HBV DNA levels) and positivity for HBeAg [9]. Despite, the high levels of viral protein and DNA, overt liver inflammation and damage are minimal. CHB carriers may progress into the second stage, the "HBeAg positive hepatitis" phase, with hepatic flares in which liver inflammation, characterized by elevated levels of alanine aminotransferase (ALT), and damage (fibrosis) may occur [7,9].

Transition to the third stage occurs with the loss of viral HBeAg and the presence of antibodies targeting HBeAg (anti-HBe) [9]. During this phase called "HBeAg-negative infection", individuals show lower HBV viremia and ALT with less liver inflammation. However, some patients may develop "HBeAg-negative chronic hepatitis" with higher levels of viral replication and hepatic or ALT flares [7,9]. These generally occur with the presence of HBV precore or basal core promoter (BCP) mutations that disrupt $\mathrm{HBeAg}$ production, but maintains or enhances viral replication $[8,9,12]$. BCP mutations present within the core promoter alter transcription from the viral covalently closed circular (ccc)DNA, which serves as the highly persistent template and replicative intermediate of $\mathrm{HBV}$. As a consequence of $\mathrm{BCP}$ mutations, precore RNA, utilized to produce $\mathrm{HBeAg}$, is reduced in favor of an increased pre-genomic (pg)RNA production that is required for the synthesis of new viral progeny [12]. The final phase is the HBsAg negative phase, which may occur either spontaneously or with treatment, and may be associated with the development of anti-HBs antibodies (seroconversion). This is associated with improved prognostic outcomes including reduced risks of cirrhosis and HCC $[9,13]$. This has been defined by the scientific community as a "functional cure" indicating robust host immune control and/or transcriptionally silent HBV cccDNA. However, only a small proportion of $\mathrm{CHB}$ carriers achieve 
a functional cure, despite many years of oral antiviral therapy with nucleos/tide analogues (NAs). A complete virological or sterilizing cure (i.e., physical clearance of HBV cccDNA and removal of integrated $\mathrm{HBV}$ ) is not possible with currently approved therapies.

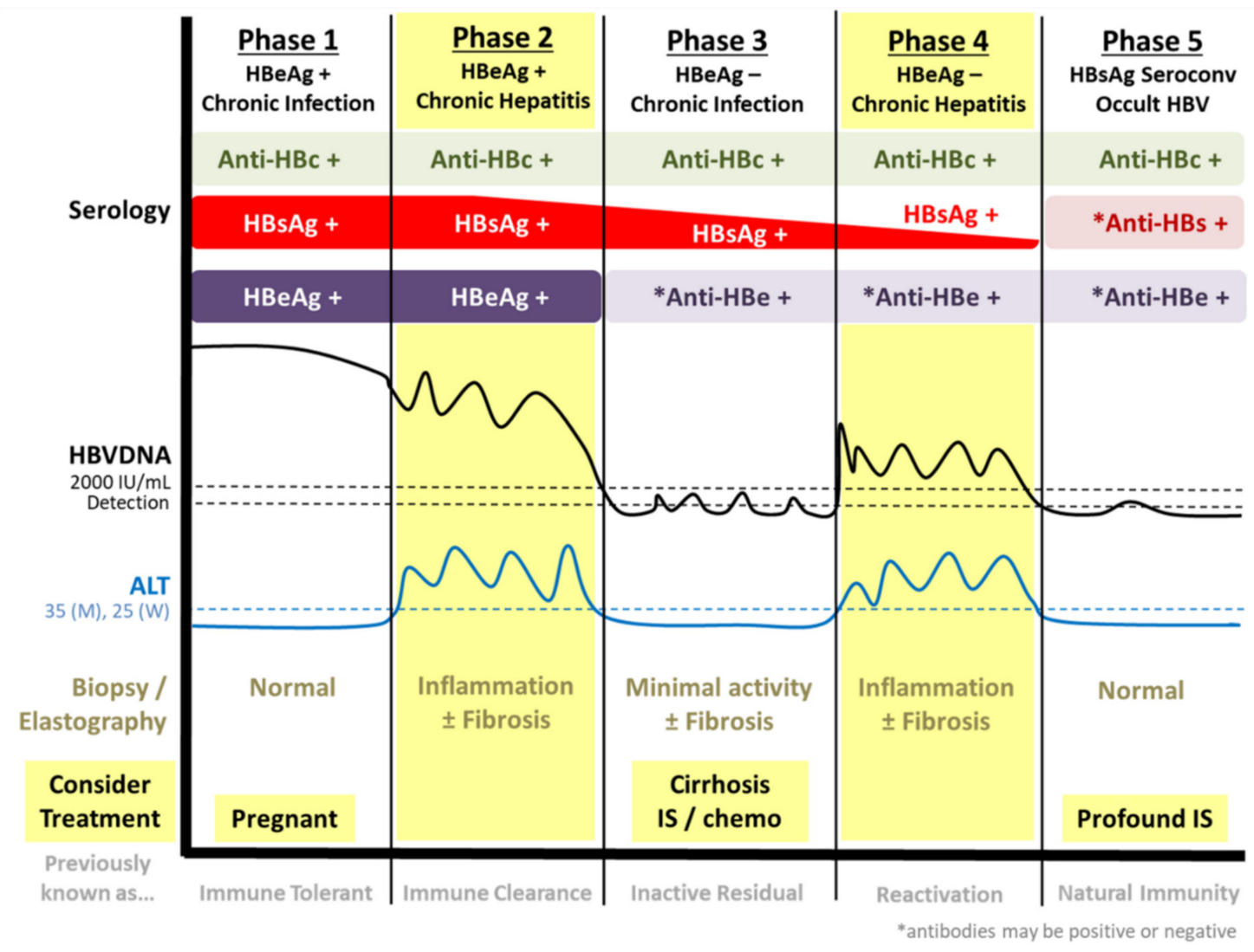

Figure 1. Phases of chronic hepatitis B infection ( $\mathrm{CHB}$ ) natural history. $\mathrm{CHB}$ is differentiated into HBeAg positive (phases 1-2) and negative phases (3-5) as well as phases of chronic hepatitis (phases 2 and 4). Chronic hepatitis phases are characterized with ALT flares, fluctuating Hepatitis B Virus (HBV) DNA levels, as well as liver damage and inflammation. Generally, anti-viral therapy is recommended during chronic hepatitis phases to reduce liver damage and suppress viral replication. However, treatment may also be beneficial for pregnant, cirrhotic, and/or immunosuppressed individuals. $\mathrm{ALT}=$ alanine aminotransferase $\mathrm{HBc}=\mathrm{HBV}$ core $\mathrm{HBsAg}=\mathrm{HBV}$ surface antigen; $\mathrm{HBeAg}=\mathrm{HBV}$ e antigen; IS = immunosuppression.

\subsection{Current Treatment of Chronic HBV Infection}

Currently approved first-line antiviral therapies for $\mathrm{CHB}$ infection include pegylated-interferon alpha (PEG-IFN $\alpha)$ or potent NAs such as tenofovir disoproxil fumarate (TDF), tenofovir alafenamide (TAF), and entecavir (ETV). HBV is a weak inducer of innate immunity (type IIFNs), thereby evading efficient immune detection and elimination of the virus [14]. Thus, the mechanisms underlying PEG-IFN targeting of HBV primarily involve harnessing the host innate immune system to target viral replication and replicative intermediates through multi-faceted approaches [15]. Indeed, studies have demonstrated the capability of IFN in inducing expression and activation of innate anti-viral interferon stimulated genes/proteins, which serves to effectively inhibit HBV replication [16-21]. Activation of interferon stimulated genes (ISGs) including, but not limited to, the apolipoprotein B mRNA editing enzyme (APOBEC)3 family, MX2, ISG20, and the TRIM family have been described with innate anti-HBV effects [16-21]. Furthermore, studies have reported the capability of IFN $\alpha$ therapy to inhibit viral replication and suppress HBV gene expression through epigenetic modulation of the HBV cccDNA [22,23]. PEG-IFN $\alpha$ treatment can be associated with higher rates of HBsAg clearance/loss 
(i.e., negative HBsAg serology by approved commercial ELISA assays) and, therefore, achievement of a functional cure. However, these rates seem to be genotype specific with improved treatment responses in HBV genotype A [8,24,25].

NAs inhibit the viral reverse transcriptase (RT) enzyme, an essential component in the viral life cycle, thereby attenuating production of new HBV particles. However, NAs do not directly target the HBV cccDNA and only a small minority of patients on therapy eventually develop HBsAg clearance (HBsAg negative/loss), which serves as a marker of viral suppression or functional cure [7,26]. Therefore, NAs are typically life-long treatments for CHB patients. Despite these disadvantages, NAs induces substantial reduction of HBV viral load with minimum adverse side-effects, which effectively prevents and delays the progression of CHB to cirrhosis or HCC in most patients $[27,28]$. Treatment for $\mathrm{CHB}$ is recommended primarily during phases of chronic hepatitis in which liver inflammation and fibrosis occurs alongside ALT flares (phases 2 and 4; Figure 1) [29,30]. However, certain CHB carriers will benefit from treatment during pregnancy (to prevent mother to child transmission), or if cirrhotic or immunosuppressed. In particular, numerous studies have demonstrated the effectiveness and safety of NA therapies, such as TDF, in reducing the risk of HBV immunoprophylaxis failures and mother-to-child transmission with lowering of maternal HBV viremia during pregnancy [31-37].

\section{Genetic Variations within HBV}

\subsection{HBV Genotypes}

CHB has a complex natural history, mediated by a dynamic interplay between the host immune response, susceptible host cells, and the virus. The outcome of HBV infections, response to treatment, and risk of HCC development, has been linked to viral heterogeneity. HBV genetic variants within the $\mathrm{HBV}$ preS1 or $\mathrm{X} /$ basal core promotor/pre-core $(\mathrm{X} / \mathrm{BCP} / \mathrm{PC})$ regions are associated with treatment failure and varying risk of HCC. In addition, deletion of viral domains such as the HBV preS region may also contribute towards risks of HCC or recurrence of HCC, such as the recent reports by Teng et al. [38] $\mathrm{HBV}$ is currently classified into 10 different genotypes, labeled $\mathrm{A}$ to $\mathrm{J}$, which are defined as $>7.5 \%$ genetic divergence within the full genome sequence of the virus [39,40]. Furthermore, HBV is separated into a number of subgenotypes defined as 4 to $7.5 \%$ genetic divergence [41,42]. Traditionally, over 30 different HBV subgenotypes have been identified and classified [41]. However, recent studies utilizing powerful sequencing data and phylogenetic analysis have suggested a careful revision of the number and standardization of subgenotypes [42,43]. HBV genotypes are typically geographically distributed. For example, genotype B and C are endemic in the Southeast Asia, including China and Japan. Countries that experience larger influxes of immigration from a variety of regions worldwide, such as Canada, demonstrate a more diverse array of genotypes [44,45]. Different genotypes have been observed to impact treatment response as well as HCC risk, age of onset, and prognosis (Figure 2). CHB carriers with HBV genotype A show better treatment outcomes with PEG-IFN $\alpha$ use including $\mathrm{HBeAg}$, HBsAg seroconversion, and reduced viremia [24,25,46-48]. In addition, comparisons between genotype $B$ and $C$ have revealed better outcomes to PEG-IFN $\alpha$ in CHB carriers with predominantly genotype B infection $[48,49]$. Furthermore, individuals infected predominantly with HBV genotype $\mathrm{C}$ or genotype $\mathrm{D}$ have a higher risk of developing cirrhosis and HCC in comparison to genotype $\mathrm{B}$ or A, respectively $[39,50,51]$. Other studies have demonstrated that early onset non-cirrhotic HCC is more common in $\mathrm{HBV}$ genotype $\mathrm{B}$ patients whereas genotype $\mathrm{C}$ is associated with later onset cirrhotic HCC $[50,52,53]$. 


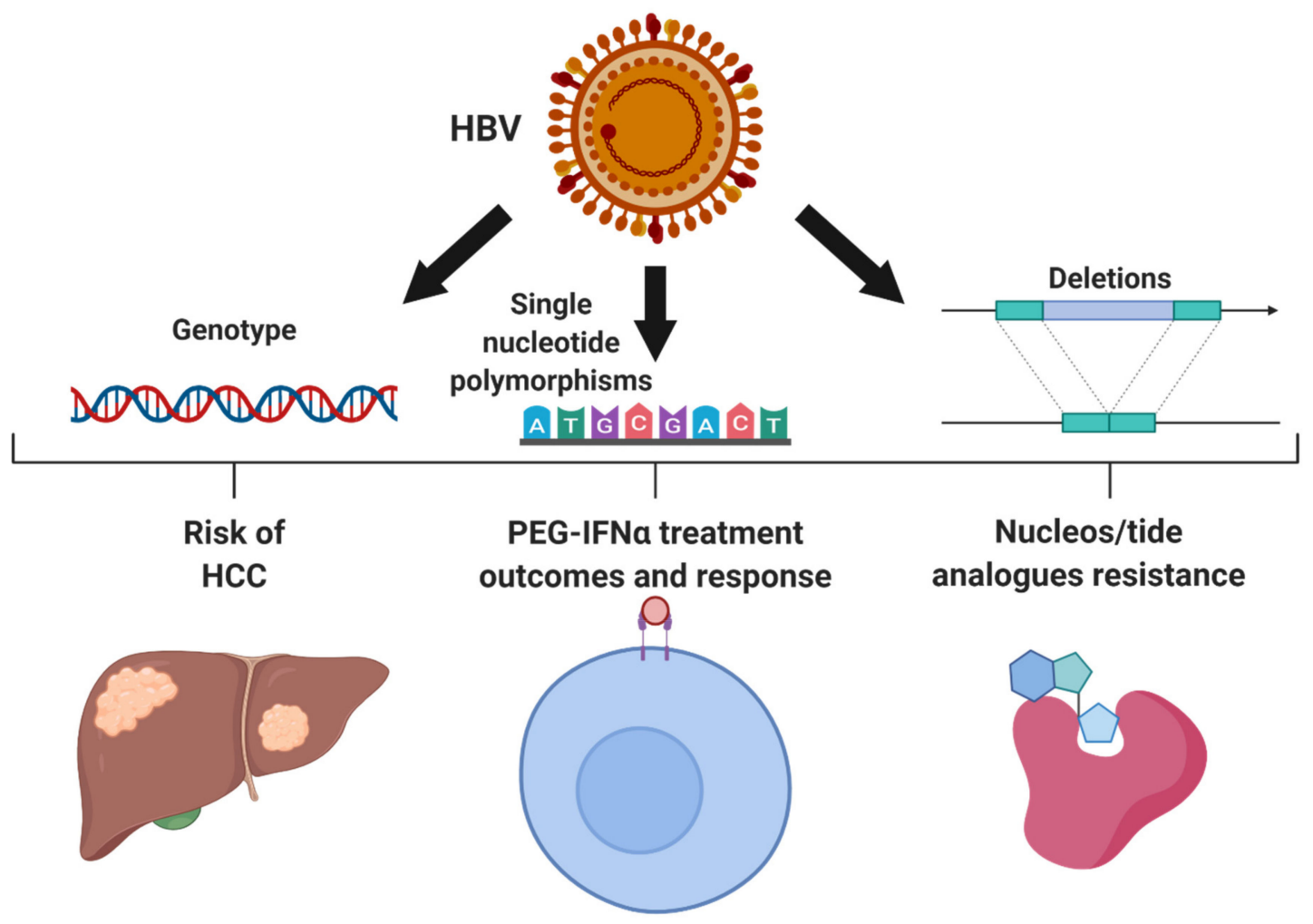

Figure 2. Impacts of Hepatitis B Virus (HBV) genetic variants including genotype, single nucleotide polymorphisms, and deletions of genetic regions. Certain genotypes of HBV are recognized to have higher risks of hepatocellular carcinoma (HCC) and better outcomes to anti-HBV therapeutics such as pegylated-interferon alpha (PEG-IFN $\alpha$ ). Similarly, viral genetic polymorphisms particularly in the HBV X/basal core promoter/precore region and the surface region influence HCC risks, PEG-IFN $\alpha$ therapy and viral resistance to nucleos/tide analogues (NA). Figure constructed using Biorender.com.

\subsection{Resistance to Anti-Viral Treatment}

Due to the error-prone method of viral replication via the HBV polymerase, the HBV population within a host exists as quasi-species. Moreover, studies evaluating lymphoid cells (peripheral blood mononuclear cells (PBMCs)) in CHB carriers have reported different genotypes exist within the plasma and PBMCs $[54,55]$. These genotype discrepancies likely arose due to different evolutionary and environmental pressures amongst the reservoirs including antiviral treatment exposure, targeting by the immune system, or genetic drift [54-56]. Thus, the viral populations in these separate cellular reservoirs diverged genetically despite originating from a common source. It is important to note that $\mathrm{CHB}$ carriers harboring certain viral genetic variations have been demonstrated to experience different outcomes to anti-viral treatment. Specific mutations within the precore (position 1896) and $\mathrm{BCP}$ region (positions 1762 and 1764) of $\mathrm{HBV}$ are associated with reduced responses to PEG-IFN $\alpha$ therapy $[46,57,58]$. CHB carriers containing either one of more of these mutations were less likely to experience HBeAg and HBsAg clearance as well as reduction in HBV DNA in comparison to individuals harboring wild-type virus [57,58].

Mutations in HBV have also been associated with resistance against NA therapy, especially first-generation NA, such as lamivudine (Figure 2). Most of these mutations are present within the HBV polymerase, which encodes for the reverse transcriptase capability of HBV. These mutations have been well-described in previously published review articles $[8,12,59,60]$. Second generation oral NA therapies, such as ETV, TDF, and TAF are advantageous for a significantly higher barrier to resistance and viral breakthrough. Anti-HBV resistance to ETV requires a minimum of three different mutations with the HBV polymerase and occurs in $~ 1-2 \%$ of treatment naïve individuals [59]. 
Long-term studies have revealed continual viral suppression with TDF despite treatment for up to 10 years [61-64]. Registration studies of CHB carriers on long-term TDF treatment have reported no identifiable mutations associated with resistance after 8 and 10 years of continuous therapy [62,64]. $\mathrm{TAF}$, the more recently approved formulation of tenofovir, also appears to show a high barrier to the development of viral resistance. A recent randomized trial comparing TAF vs. TDF in $1298 \mathrm{CHB}$ carriers demonstrated comparable rates of virological breakthrough with no identified HBV mutations associated with treatment resistance after 96 weeks of treatment [65]. However, two recent reports have identified TDF resistance mutations within the HBV genome. Both studies report a combination of four mutations (rtL180M/T184L/M204V/A200V or rtS106C/H126Y/D134E/L269I) are required for the development of resistance [66,67]. However, these quadruple mutations were reported in only one and two $\mathrm{CHB}$ carriers in the respective studies and the frequency of these genetic combinations within the $\mathrm{CHB}$ population is likely rare. Additional research is warranted to better characterize and validate these mutations. Nonetheless, the widespread use of long-term TDF and TAF therapies outside of controlled trial studies, may lead to further issues with antiviral resistant HBV genetic variants.

\subsection{HBV Single Nucleotide Polymorphisms Associated with HCC}

In addition to influencing treatment response and outcomes, genetic variations within HBV are linked to HCC (Figure 2). Indeed, mutations within the preS1 and preS2 regions of the virus have been reported and shown to induce hepatocarcinogenesis [68-70]. Mutations of these regions result in impaired secretion of HBV virions and HBs subviral particles leading to an accumulation of unfolded viral proteins within the cellular ER [71,72]. It is important to note that some of the mutations may arise due to selective pressure with the use of antiviral therapies. Most notably, due to the overlapping nature of the HBV genome, the rtA181T mutation, which can confer NA therapy resistance, results the well-characterized sW172* mutation associated with truncated surface proteins [59]. The preS mutations can contribute to the histological phenotype of type II ground-glass hepatocytes [72,73]. Consequently, hepatocytes containing HBV preS mutants exhibit ER stress response, oxidative DNA damage, increased inflammation and undergo cellular apoptosis $[71,72,74]$. These cellular processes facilitate the neoplastic transformation of hepatocytes and the induction of HCC.

In addition to the preS mutations, genetic variants of $\mathrm{HBV}$ within the $\mathrm{X} / \mathrm{BCP} / \mathrm{PC}$, have also been associated with an increased-and in some cases decreased-risk of developing cirrhosis and HCC. Some of the oncogenic variants in this region have been observed at higher frequencies in certain genotypes, which likely is reflected in the difference in HCC risks amongst HBV genotypes. For example, the double mutations A1762T and G1764A are more frequently observed in genotype C. Many variants in this region have been identified from large epidemiological studies generally from Asian populations [75]. Most notably, the A1762T and G1764A double mutations are consistently associated with HBV induced cirrhosis and HCC [68,75-80]. In addition, T1674C/G, A1752G, T1753V, T1768A, C1773T, A1846T, G1896A, and G1899A also influence HCC risks [68,75,77-80]. Amongst these variants, only the presence of A1752G is correlated with a decreased cirrhosis and HCC risk [78].

Alterations in the $\mathrm{HBx}$ protein are associated with mutations within the $\mathrm{X} / \mathrm{BCP} / \mathrm{PC}$ region and can lead to HCC development. Due to the overlapping nature of the HBV genome, the mutations directly affect the genetic coding sequence of $\mathrm{HBx}$. A research study by Yan and colleagues exploring the quadruple mutant of A1762T/G1764A/T1753A/T1768A showed an overall downregulation of p53 in comparison to wild-type HBV X [81]. In addition, these mutations are also capable of influencing the non-structural protein, HBeAg. The variant G1896A is well recognized for the ability of introducing a premature stop codon within the HBeAg transcript resulting in a significantly truncated protein and HBeAg-negative serology [82,83]. Other mutations in this region, including the A1762T/G1764A double mutations, also result in reduced $\mathrm{HBeAg}$ production and expression by altering the wild-type $\mathrm{BCP}$, a component of the core promoter that encodes for precore (HBeAg) RNA [83]. Interestingly, these BCP genetic variants induces a transcriptional shift resulting in an associated decrease in precore RNA (and subsequent HBeAg expression) with a corresponding increase in viral replication through enhanced 
pgRNA expression. Due to this phenotype, a combination of these mutations is thought to be related to the risk of hepatic flares or high viral load levels in HBeAg-negative CHB cases (Figure 1) $[7,84,85]$. However, many of the $\mathrm{X} / \mathrm{BCP} / \mathrm{PC}$ mutants that have been linked to HCC risk in epidemiological studies are still poorly understood particularly with regards to the molecular biology and phenotypic consequences. The overall impact of these specific genetic variants on either the viral life cycle or cellular processes are poorly characterized.

\section{Unique Features of HBV that Impact Treatment and Oncogenesis}

\subsection{Oncogenic Implications of HBV Integration}

Integration of HBV DNA into the host genome arises with the incorporation of double stranded linear (dsl) variants of HBV (Figure 2). An estimated 10\% of HBV reverse transcription results in the synthesis of a dsIDNA form of the HBV genome due to a lack of translocation of the viral RNA primer to the 5' DR2 [86]. Similar to rcDNA, the dsIDNA can be either exocytosed from the cell as new infectious viral progeny or recycled back into the nucleus [86]. Once the dsIDNA localizes into the nucleus either through de novo secondary infection or intracellular recycling, the dsIDNA is capable of inserting into the host genome, a process primarily mediated by non-homologous end joining (NHEJ) or microhomology-mediated end joining (MMEJ) that utilizes host machinery [86-89]. These cellular mechanisms of handling double strand DNA breaks are non-specific and frequently causes deletions and insertions, which are reflected within the integrated HBV $[86,90]$. HBV integration is not necessary for a productive HBV life cycle and results in a dead-end infection as the integrated virus is incapable of producing viral progeny [86]. It has been estimated that HBV integration occurs at a rate of 1 in 1000 hepatocytes within an infected liver [91]. Integration of HBV likely occurs shortly if not immediately after infection as suggested by studies in both the clinical and in vitro settings. HBV integration has been detected from liver tissues from early stages of $\mathrm{CHB}$ (immune tolerant or HBeAg+ chronic infection, phase 1 in Figure 1) [92,93]. In addition, in vitro studies have shown that HBV integration in immortalized hepatocyte cell lines can occur even within hours after entry into a new host cell [91,94].

Integration of $\mathrm{HBV}$ is thought to occur at random sites and has been detected in a wide variety of genes, but preferential sites for HBV integration include host genomic regions prone to dsDNA breaks or fragile sites largely due to the use of NHEJ and MMEJ mechanism [89]. Furthermore, recent studies have observed increased detection of HBV integration within coding regions, open chromatin areas, and regions with higher gene expression [95,96]. It is hypothesized that HBV integration is insufficient by itself to induce cancer, but instead facilitates hepatocarcinogenesis $[97,98]$. Integrations associated with oncogenic implications would likely provide survival advantages, which are selected for during clonal expansion of HCC progenitor cells. Thus, recurrent integration sites have been characterized from HCC tissues, many of which occur within genes that play a role in cellular processes implicated in oncogenesis. For example, one of the more frequently reported integration site is the human telomerase reverse transcriptase (hTERT) gene [52,96,99-103]. The hTERT is a well-known oncogene found to be one of the most frequent genetic alterations present in early developing HCC suggesting a role in development and pathogenesis of HCC $[104,105]$. This gene permits cellular immortalization by activating telomerase activity and is upregulated in cells integrated with HBV $[52,96,100,101]$. In addition to the hTERT, HBV recurrent integration events has been found within other genes implicated in oncogenesis and malignant transformation, such as the MLL4 and SERCA1 genes $[96,101,103,106,107]$. HBV integration may also influence the expression or production of non-coding RNA, which are increasingly reported to impact carcinogenesis of many cancers including HCC $[108,109]$. Indeed, Lau et al. has elegantly characterized a specific HBV integration site, which generates a novel long non-coding RNA (coined HBx-LINE1) with oncogenic implications [110]. 


\subsection{Extrahepatic HBV Infection and Lymphotropism}

HBV is a hepatotropic virus that infects and establishes reservoirs in hepatocytes. Studies in the woodchuck hepatitis virus (WHV) model of HBV show that WHV is also a lymphotropic virus [111-114]. Several research groups have suggested that the lymphoid system also serves as an HBV reservoir (Figure 3). Important HBV replicative intermediates and infection markers have been identified in extrahepatic lymphoid tissues including the spleen, lymphoid nodes, and lymphoid cells [54,56,115-121]. In fact, Lee et al., Chemin et al., and Trippler et al. have independently demonstrated that the virus is universally present in multiple immune cell subsets derived from HBV-infected individuals [122-124]. Studies by Yan et al. and Huang et al. reported that naïve primary PBMCs and hematopoietic stem cells, respectively, can be infected in vitro with clinically derived HBV $[125,126]$. Our recent work demonstrated that HBV derived from the lymphoid reservoir (PBMCs) can be stimulated with mitogens that induce an increase in multiple viral replication markers such as HBV DNA, cccDNA, and RNA both intracellularly and extracellularly [127]. Independent studies by Bouffard et al. and Yan et al. reported that comparable findings $[125,128]$. Limited studies of lymphoid-derived HBV have demonstrated the infectious potential of this reservoir. Brind et al. reported an important clinical implication of this extrahepatic reservoir in that PBMC-derived HBV was hypothesized as the infectious source responsible for re-infection of the liver post-transplantation [117]. The findings from these studies are particularly noteworthy as it suggests that the lymphoid cell reservoir is not only susceptible for HBV infection, but are also capable of harboring infectious HBV virions.

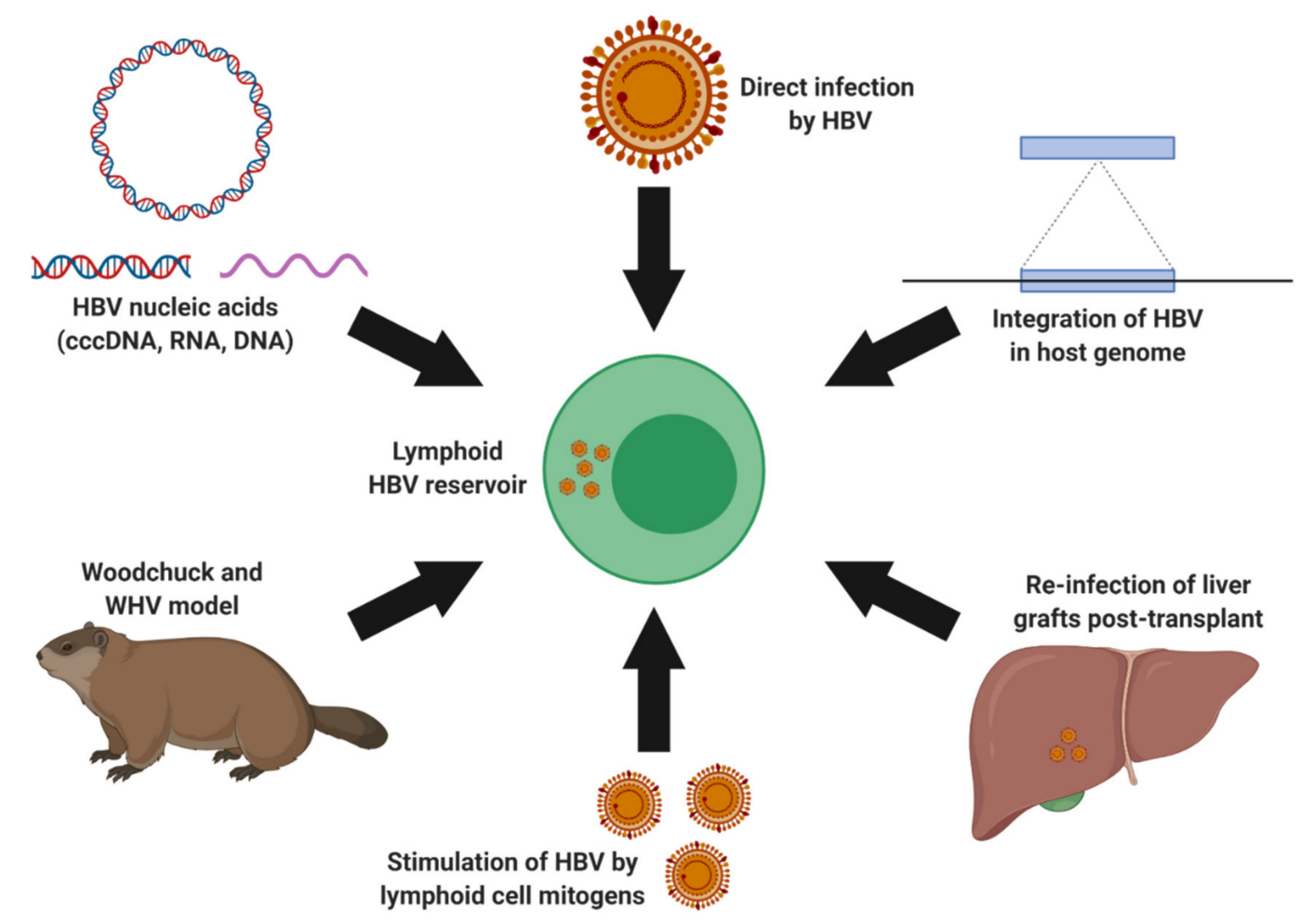

Figure 3. Evidence for a lymphoid HBV reservoir. The woodchuck and woodchuck hepatitis virus (WHV), a useful animal model system for hepadnaviruses, has established lymphoid infection by WHV [111-114]. Several research groups have suggested the detection of viral nucleic acids including HBV cccDNA, RNA, and DNA as well as viral integration within lymphoid cells [54,56,115-124]. Furthermore, direct infection of lymphoid cells with clinically derived HBV has been achieved in vitro $[125,126]$. HBV derived from the lymphoid reservoirs has been stimulated with the use of mitogens $[125,127,128]$. Furthermore, lymphoid derived HBV is suggested to be implicated in the re-infection of liver grafts post-liver transplant [117]. Figure created using Biorender.com. 
The presence of HBV within the lymphoid cells may also contribute towards the development of hematological neoplasms. Indeed, a number of epidemiological studies have reported associations of CHB with higher risks of non-Hodgkin lymphoma, specifically diffuse large B-cell lymphoma (DLBCL) [129-136]. Although, the mechanisms underlying this clinical association have yet to be elucidated, the direct oncogenic effects of HBV within lymphoid cells may induce malignant transformation. In support of this hypothesis, a recent study by Wang et al. not only demonstrates that B-lymphocyte cell lines are infectable by HBV, but also that DLBCL tissues contain HBV infection markers such as HBV DNA and viral HBsAg, $\mathrm{HBcAg}$, as well as HBx proteins [137]. HBV integration have previously been detected within the PBMCs and hematopoietic stem cells $[116,127,138]$. This viral feature is well-recognized to contribute towards hepatocarcinogenesis and may also be implicated in oncogenesis of HBV infected lymphoid cells. Additional data including in-depth HBV integration studies of PBMCs and of lymphoid malignancies from CHB carriers are essential. In line with this theory, our recent work identified a total of 38 distinct HBV integration sites within the host genome, using the well-established Alu PCR technique [116,139], from PBMCs and tumor tissue derived from a CHB carrier with dendritic cell sarcoma (DCS), a lymphoproliferative disease [127]. In addition, viral proteins including HBV core and surface as well as HBV DNA, cccDNA, and RNA were detected within the DCS tumor. Next generation sequencing revealed the presence of genetic variants associated with increased HCC risk A1762T/G1764A in both the PBMC and DCS tumor [127]. Similarly, in a study of $40 \mathrm{HBV}$ seronegative DLBCL patients, Sinha et al. identified occult HBV infection within 27 (67.5\%) cases [140]. Furthermore, they reported the detection of HCC-associated HBV genetic variants such as $\mathrm{X} / \mathrm{BCP} / \mathrm{PC}$ and surface mutations within plasma, B-cells, and tumor tissues. The results of these recent studies highlight the potential oncological importance of HBV lymphotropism and warrant additional research to clarify the associations of $\mathrm{HBV}$ and hematological malignancies.

Despite, the recent advances in our understanding of HBV lymphotropism, numerous outstanding questions remain warranting additional research. Namely, the process of viral entry and the corresponding cellular receptor utilized for lymphoid cell infection remains elusive. Likely the HBV surface proteins mediate the interaction with a currently unknown host receptor. An intriguing possibility are the B-cell antigen receptors, which are specific for HBV surface proteins might serve as the mechanisms of lymphoid cell entry for HBV. Alternatively, non-specific receptors present on phagocytes may serve as a method of permitting HBV entry through the processes of phagocytosis, micropinocytosis, or endocytosis [141]. These mechanisms of viral entry has been reported in other chronic human lymphotropic viruses including hepatitis $C$ virus, herpesviruses, and human immunodeficiency virus [141]. Furthermore, host hepatic factors generally contribute towards the enhancement of viral transcription and replication [142]. Certainly, analogous factors might exist within lymphocytes, which have yet to be identified. An intriguing theory within HBV lymphotropism could involve the infection of progenitor or hematopoietic stem cells, which leads to the subsequent dissemination of HBV fragments, nucleic acids, and particles into differentiated cells. Indeed, the prior study by Shi et al. demonstrated the possible infectivity of hematopoietic stem cells with HBV [138]. This could also explain the distribution of HBV amongst the different immune cell subtypes, including natural killer cells, monocytes, B-lymphocytes, and T-lymphocytes as previously reported [122-124].

Utilization of the woodchuck model and WHV could also serve to contribute towards a better understanding of hepadnaviridae lymphotropism including mechanism of viral entry, host cell restriction factors, and host factors beneficial towards viral persistence or infection. However, it is important to note that many aspects of WHV biology remains unclear including the entry mechanism into woodchuck hepatocytes. Another feature of this animal model, which is important to consider is the perceived increased lymphotropic nature of WHV in comparison to HBV. Potentially there exists certain host or viral factors, which are more permissible for WHV replication within the lymphoid cells of woodchucks. In line with this possibility, a prior study by Jin et al. have demonstrated that the WHV surface proteins, and more specifically the preS1 domain, was more efficient in interacting with woodchuck lymphoid cells in comparison to hepatocytes [143]. This increased affinity for lymphoid 
cells might account for the selective infection of lymphoid cells at low levels of WHV as demonstrated by Michalak et al. [111]. Identification of additional factors implicated in the permissibility of WHV lymphotropism may contribute towards an understanding of the HBV lymphoid reservoirs present within CHB carriers.

\section{Considerations for Novel HBV Therapeutics}

\subsection{HBV Genetic Variation as Predictor Factors}

A wide variety of novel therapeutics are under development for CHB infection, hoping to achieve a functional (HBsAg loss) and/or sterilizing cure (clearance of HBV cccDNA). These include capsid assembly inhibitors, HBV entry inhibitors, and immunotherapies, such as checkpoint blockade inhibitors and RIG-1 agonists (see https://www.hepb.org/treatment-and-management/drug-watch/ for more) [144]. An important consideration moving forward is the role of HBV genotypes and genetic variants as predictors of treatment response and outcomes. Indeed, an enhanced understanding of viral genetic variations and their association with treatment response would be beneficial in the development of individually tailored curative therapy. Similar to the predictive value of genotype utilized to select patients more likely to respond to PEG-IFN $\alpha$ therapy, careful patient selection may guide the development of antivirals to benefit all persons with HBV infection, regardless of disease phase. Clinical studies with novel HBV treatment will need to consider the role of novel genetic tools and HBV biomarkers, such as high throughput sequencing and genotyping to characterize the study population and their unique viral variants.

\subsection{Occult HBV Infection}

Due to the nature of HBV integration and HBV cccDNA persistence, a sterilizing cure that eliminates all viral genomic material from infected hosts is extremely challenging. Instead, current and developing antiviral therapies focuses on achieving a "functional cure" in which viral activity is suppressed, transcriptional silencing of HBV cccDNA, with seroconversion of HBsAg (loss of HBsAg with development of anti-HBs antibodies, Phase 5 in Figure 1) [145]. Achieving HBsAg loss and a functional cure does not fully eliminate the risk factors associated with persistent $\mathrm{HBV}$ and can lead to occult hepatitis B infection (OBI). OBI is a condition defined primarily with HBsAg-negative serology despite the presence of replication competent HBV [146]. OBI cases may or may not have detectable HBV viremia due to frequently suppressed viral expression and replication. This suppression may arise primarily due to host immune system control of HBV (Figure 1) [147,148]. Typically, individuals with OBI are identified with positive HBV genome detection from at least two HBV genomic regions using highly sensitive molecular techniques, such as nested polymerase chain reaction (PCR) [146]. Nonetheless, detection and accurate genotyping of the HBV can be particularly challenging in OBI individuals with very low-level HBV viremia (<10 IU/mL or 50 virus copies/mL).

Despite the HBsAg-negativity and low-level viremia, OBI remains clinically significant as HBV may reactivate with immunosuppression and individuals with OBI have increased risks of malignant disease relative to HBV-negative individuals [149,150]. A prior study following 1217 Alaskan Natives an average of 19.6 years revealed no differences amongst those who cleared HBsAg (OBI) and those who remained HBsAg positive [151]. Indeed, HBV replicative intermediates can be frequently detected and found in HCC patients without overt CHB disease [152-155]. In fact, many cases of cryptogenic HCC (those with no known cause) have been linked to OBI [155-157]. Studies have demonstrated that oncogenic viral integration is detectable and likely poses a continual risk for malignant transformation of hepatocytes $[139,157,158]$. In addition to HCC and liver disease, reports have suggested that the presence of occult low-level HBV are also associated with extrahepatic and hematological malignancies including leukemia and lymphoma [159-161]. HBV reactivation in OBI may also be particularly problematic within patients who undergo chemotherapeutics or immunosuppressive therapies that impact host adaptive immunity. The most well-characterized cases occur in patients receiving anti-CD20 
therapy (e.g., rituximab) [162-164]. As a consequence of the disruption of host anti-HBV immunity, the virus can reactivate potentially leading to acute liver failure and fatal outcomes. These situations emphasize the appropriate identification of OBI to prevent and monitor potential HBV reactivation.

\subsection{Therapeutic Management of HBV Lymphoid Reservoirs}

HBV lymphotropism is an intriguing consideration in the natural history of HBV infection, particularly if lymphoid cells may serve as a viral reservoir capable of producing infectious HBV. Most pre-clinical studies of HBV therapeutics involve the in vitro use of immortalized cell lines (e.g., HepG2, HepG2.2.15, Huh7, and/or HepaRG) with and/or without the HBV entry receptor, sodium taurocholate cotransporting polypeptide (NTCP), as well as in vivo murine models (e.g., uPA/SCID) with humanized liver. However, it may be of interest to assess in vitro or in vivo systems for the effect of developing therapies on hepadnaviral infection within the lymphoid reservoir. The murine HBV models with humanized liver usually have defective immune systems and cells to allow for growth of xenograft liver tissue [165] and contain non-humanized lymphoid cells, which are likely not permissible to HBV infection. Thus, the development of a CHB infection system within a lymphoid cell line or primary PBMCs would be useful as an in vitro model. For in vivo studies, the use of immunocompetent animals with lymphoid cells that are naturally infected by hepadnavirus could serve as useful pre-clinical models. As previously noted, Eastern North American woodchucks (Marmota monax) susceptible to WHV, is a highly valuable animal model for human HBV infection with closely related hepadnaviral infection. Numerous studies have demonstrated the lymphotropic nature of WHV, which can replicate and produce infectious virions within the woodchuck lymphatic system [111-114].

In summary, there has been rapid development of direct acting antivirals and host targeting novel HBV agents. Increased understanding and development of tools to study the complex virology of $\mathrm{HBV}$ and the dynamic interplay with the host immune response is needed to ultimately achieve a HBV cure. Viral genetic variations can impact therapeutic development, such as refining the selection and monitoring of potential treatment responders. The role of HBV lymphoid reservoirs as a source of liver cell re-infection, especially in OBI, and extrahepatic complications remains controversial. Moreover, even patients who achieve a functional cure (HBsAg clearance) late in life, may harbor OBI and remain at risk for HCC and overt HBV reactivation with potent immunosuppression.

Author Contributions: K.C.K.L. and C.S.C. wrote and drafted the manuscript. K.C.K.L. and K.W.B. designed and constructed to figures. All authors edited and reviewed the manuscript and approved the final version.

Funding: CSC has received funding from Gilead, GSK and Janssen for investigator initiated research activities of the Canadian HBV Network (www.canadianhbvnetwork.ca).

Conflicts of Interest: The authors declare no conflict of interest.

\section{References}

1. WHO. Global Hepatitis Report 2017; World Health Organization: Geneva, Switzerland, 2017.

2. Naghavi, M.; Abajobir, A.A.; Abbafati, C.; Abbas, K.M.; Abd-Allah, F.; Abera, S.F.; Aboyans, V.; Adetokunboh, O.; Afshin, A.; Agrawal, A.; et al. Global, regional, and national age-sex specific mortality for 264 causes of death, 1980-2016: A systematic analysis for the Global Burden of Disease Study 2016. Lancet 2017, 390, 1151-1210. [CrossRef]

3. Schweitzer, A.; Horn, J.; Mikolajczyk, R.T.; Krause, G.; Ott, J.J. Estimations of worldwide prevalence of chronic hepatitis B virus infection: A systematic review of data published between 1965 and 2013. Lancet 2015, 386, 1546-1555. [CrossRef]

4. Lau, K.C.; Shaheen, A.A.; Aspinall, A.A.; Ba, T.R.; Mba, K.Q.; Congly, S.E.; Borman, M.A.; Jayakumar, S.; Eksteen, B.; Lee, S.S.; et al. Hepatitis B virus testing and linkage to care in a Canadian urban tertiary referral centre: A retrospective cohort study. CMAJ Open 2017, 5, E431-E436. [CrossRef] [PubMed]

5. Trépo, C.; Chan, H.L.Y.; Lok, A. Hepatitis B virus infection. Lancet 2014, 384, 2053-2063. [CrossRef] 
6. Ginzberg, D.; Wong, R.J.; Gish, R. Global HBV burden: Guesstimates and facts. Hepatol. Int. 2018, 12, 315-329. [CrossRef]

7. Yuen, M.-F.; Chen, D.-S.; Dusheiko, G.M.; Janssen, H.L.A.; Lau, D.T.Y.; Locarnini, S.A.; Peters, M.G.; Lai, C.-L. Hepatitis B virus infection. Nat. Rev. Dis. Prim. 2018, 4, 18035. [CrossRef] [PubMed]

8. Rajoriya, N.; Combet, C.; Zoulim, F.; Janssen, H.L. How viral genetic variants and genotypes influence disease and treatment outcome of chronic hepatitis B. Time for an individualised approach? J. Hepatol. 2017, 67, 1281-1297. [CrossRef] [PubMed]

9. Coffin, C.S.; Fung, S.K.; Alvarez, F.; Cooper, C.L.; Doucette, K.; Fournier, C.; Kelly, E.; Ko, H.H.; Ma, M.M.; Martin, S.R.; et al. Management of Hepatitis B Virus Infection: 2018 Guidelines from the Canadian Association for the Study of the Liver and Association of Medical Microbiology and Infectious Disease Canada. Can. Liver J. 2018, 1, 156-217. [CrossRef]

10. Gerlich, W.H.; Glebe, D.; Kramvis, A.; Magnius, L. Peculiarities in the designations of hepatitis B virus genes, their products, and their antigenic specificities: A potential source of misunderstandings. Virus Genes 2020, 56, 109-119. [CrossRef]

11. Tsai, K.-N.; Kuo, C.-F.; Ou, J.-H.J. Mechanisms of Hepatitis B Virus Persistence. Trends Microbiol. 2018, 26, 33-42. [CrossRef]

12. Tong, S.; Revill, P. Overview of hepatitis B viral replication and genetic variability. J. Hepatol. 2016, 64, S4-S16. [CrossRef]

13. Yuen, M.-F.; Wong, D.K.; Fung, J.; Ip, P.P.C.; But, D.; Hung, I.F.-N.; Lau, K.; Yuen, J.C.; Lai, C.-L. HBsAg Seroclearance in Chronic Hepatitis B in Asian Patients: Replicative Level and Risk of Hepatocellular Carcinoma. Gastroenterology 2008, 135, 1192-1199. [CrossRef] [PubMed]

14. Bertoletti, A.; Gehring, A.J. Immune Therapeutic Strategies in Chronic Hepatitis B Virus Infection: Virus or Inflammation Control? PLoS Pathog. 2013, 9, e1003784. [CrossRef]

15. Konerman, M.A.; Lok, A.S. Interferon Treatment for Hepatitis B. Clin. Liver Dis. 2016, 20, 645-665. [CrossRef] [PubMed]

16. Tan, G.; Yi, Z.; Song, H.; Xu, F.; Li, F.; Aliyari, R.; Zhang, H.; Du, P.; Ding, Y.; Niu, J.; et al. Type-I-IFN-Stimulated Gene TRIM5gamma Inhibits HBV Replication by Promoting HBx Degradation. Cell Rep. 2019, 29, 3551-3563. [CrossRef] [PubMed]

17. Tan, G.; Xu, F.; Song, H.; Yuan, Y.; Xiao, Q.; Ma, F.; Qin, F.X.-F.; Cheng, G. Identification of TRIM14 as a Type I IFN-Stimulated Gene Controlling Hepatitis B Virus Replication by Targeting HBx. Front. Immunol. $2018,9$. [CrossRef]

18. Tan, G.; Xiao, Q.; Song, H.; Ma, F.; Xu, F.; Peng, D.; Li, N.; Wang, X.; Niu, J.; Gao, P.; et al. Type I IFN augments IL-27-dependent TRIM25 expression to inhibit HBV replication. Cell. Mol. Immunol. 2017, 15, 272-281. [CrossRef] [PubMed]

19. Wang, Y.-X.; Niklasch, M.; Liu, T.; Wang, Y.; Shi, B.; Yuan, W.; Baumert, T.F.; Yuan, Z.; Tong, S.; Nassal, M.; et al. Interferon-inducible MX2 is a host restriction factor of hepatitis B virus replication. J. Hepatol. 2020, 72, 865-876. [CrossRef]

20. Leong, C.R.; Funami, K.; Oshiumi, H.; Mengao, D.; Takaki, H.; Matsumoto, M.; Aly, H.H.; Watashi, K.; Chayama, K.; Seya, T. Interferon-stimulated gene of $20 \mathrm{kDa}$ protein (ISG20) degrades RNA of hepatitis B virus to impede the replication of HBV in vitro and in vivo. Oncotarget 2016, 7, 68179-68193. [CrossRef]

21. Liu, Y.; Nie, H.; Mao, R.; Mitra, B.; Cai, D.; Yan, R.; Guo, J.-T.; Block, T.M.; Mechti, N.; Guo, H. Interferon-inducible ribonuclease ISG20 inhibits hepatitis B virus replication through directly binding to the epsilon stem-loop structure of viral RNA. PLoS Pathog. 2017, 13, e1006296. [CrossRef]

22. Belloni, L.; Allweiss, L.; Guerrieri, F.; Pediconi, N.; Volz, T.; Pollicino, T.; Petersen, J.; Raimondo, G.; Dandri, M.; Levrero, M. IFN- $\alpha$ inhibits HBV transcription and replication in cell culture and in humanized mice by targeting the epigenetic regulation of the nuclear cccDNA minichromosome. J. Clin. Investig. 2012, 122, 529-537. [CrossRef] [PubMed]

23. Liu, F.; Campagna, M.; Qi, Y.; Zhao, X.; Guo, F.; Xu, C.; Li, S.; Li, W.; Block, T.M.; Chang, J.; et al. Alpha-Interferon Suppresses Hepadnavirus Transcription by Altering Epigenetic Modification of cccDNA Minichromosomes. PLoS Pathog. 2013, 9, e1003613. [CrossRef] [PubMed]

24. Buster, E.H.; Hansen, B.E.; Lau, G.K.; Piratvisuth, T.; Zeuzem, S.; Steyerberg, E.W.; Janssen, H.L.A. Factors That Predict Response of Patients with Hepatitis B e Antigen-Positive Chronic Hepatitis B to Peginterferon-Alfa. Gastroenterology 2009, 137, 2002-2009. [CrossRef] [PubMed] 
25. Flink, H.J.; Van Zonneveld, M.; Hansen, B.E.; De Man, R.A.; Schalm, S.W.; Janssen, H.L.; for the HBV 99-01 Study Group. Treatment with Peg-Interferon alpha-2b for HBeAg-Positive Chronic Hepatitis B: HBsAg Loss Is Associated with HBV Genotype. Am. J. Gastroenterol. 2006, 101, 297-303. [CrossRef]

26. Chan, H.L.Y.; Fung, S.; Seto, W.K.; Chuang, W.-L.; Chen, C.-Y.; Kim, H.J.; Hui, A.J.; Janssen, H.L.A.; Chowdhury, A.; Tsang, T.Y.O.; et al. Tenofovir alafenamide versus tenofovir disoproxil fumarate for the treatment of HBeAg-positive chronic hepatitis B virus infection: A randomised, double-blind, phase 3, non-inferiority trial. Lancet Gastroenterol. Hepatol. 2016, 1, 185-195. [CrossRef]

27. Chen, C.-J.; Yang, H.-I.; Su, J.; Jen, C.-L.; You, S.-L.; Lu, S.-N.; Huang, G.-T.; Iloeje, U.H.; for the REVEAL-HBV Study Group. Risk of Hepatocellular Carcinoma Across a Biological Gradient of Serum Hepatitis B Virus DNA Level. JAMA 2006, 295, 65. [CrossRef]

28. Lai, C.-L.; Yuen, M.-F. Prevention of hepatitis B virus-related hepatocellular carcinoma with antiviral therapy. Hepatology 2013, 57, 399-408. [CrossRef]

29. EASL. EASL 2017 Clinical Practice Guidelines on the management of hepatitis B virus infection. J. Hepatol. 2017, 67, 370-398. [CrossRef]

30. Terrault, N.A.; Lok, A.S.F.; McMahon, B.J.; Chang, K.-M.; Hwang, J.P.; Jonas, M.M.; Brown, R.S., Jr.; Bzowej, N.H.; Wong, J.B. Update on prevention, diagnosis, and treatment of chronic hepatitis B: AASLD 2018 hepatitis B guidance. Hepatology 2018, 67, 1560-1599. [CrossRef]

31. Kochaksaraei, G.S.; Castillo, E.; Osman, M.; Simmonds, K.; Scott, A.N.; Oshiomogho, J.I.; Lee, S.S.; Myers, R.P.; Martin, S.R.; Coffin, C.S. Clinical course of 161 untreated and tenofovir-treated chronic hepatitis B pregnant patients in a low hepatitis B virus endemic region. J. Viral Hepat. 2015, 23, 15-22. [CrossRef]

32. Pan, C.Q.; Duan, Z.; Dai, E.; Zhang, S.; Han, G.; Wang, Y.; Zhang, H.; Zou, H.; Zhu, B.; Zhao, W.; et al. Tenofovir to Prevent Hepatitis B Transmission in Mothers with High Viral Load. N. Engl. J. Med. 2016, 374, 2324-2334. [CrossRef] [PubMed]

33. Hyun, M.H.; Lee, Y.-S.; Kim, J.H.; Je, J.H.; Yoo, Y.J.; Yeon, J.E.; Byun, K.S. Systematic review with meta-analysis: The efficacy and safety of tenofovir to prevent mother-to-child transmission of hepatitis B virus. Aliment. Pharmacol. Ther. 2017, 45, 1493-1505. [CrossRef] [PubMed]

34. Boucheron, P.; Lu, Y.; Yoshida, K.; Zhao, T.; Funk, A.L.; Lunel-Fabiani, F.; Guingané, A.; Tuaillon, E.; Van Holten, J.; Chou, R.; et al. Accuracy of HBeAg to identify pregnant women at risk of transmitting hepatitis B virus to their neonates: A systematic review and meta-analysis. Lancet Infect. Dis. 2020. [CrossRef]

35. Gerlich, W.H. Good news from WHO on prevention of peripartum hepatitis B transmission. Lancet Infect. Dis. 2020. [CrossRef]

36. Funk, A.L.; Lu, Y.; Yoshida, K.; Zhao, T.; Boucheron, P.; Van Holten, J.; Chou, R.; Bulterys, M.; Shimakawa, Y. Efficacy and safety of antiviral prophylaxis during pregnancy to prevent mother-to-child transmission of hepatitis B virus: A systematic review and meta-analysis. Lancet Infect. Dis. 2020. [CrossRef]

37. WHO. Prevention of Mother-to-Child Transmission of Hepatitis B Virus: Guidelines on Antiviral Prophylaxis in Pregnancy; World Health Organization: Geneva, Switzerland, 2020.

38. Teng, C.-F.; Li, T.-C.; Huang, H.-Y.; Lin, J.-H.; Chen, W.-S.; Shyu, W.-C.; Wu, H.-C.; Peng, C.-Y.; Su, I.-J.; Jeng, L.-B. Next-Generation Sequencing-Based Quantitative Detection of Hepatitis B Virus Pre-S Mutants in Plasma Predicts Hepatocellular Carcinoma Recurrence. Viruses 2020, 12, 796. [CrossRef]

39. Lin, C.-L.; Kao, J.-H. Hepatitis B Virus Genotypes and Variants. Cold Spring Harb. Perspect. Med. 2015, 5, a021436. [CrossRef]

40. Liu, C.-J.; Kao, J.-H. Global perspective on the natural history of chronic hepatitis B: Role of hepatitis B virus genotypes A to J. Semin. Liver Dis. 2013, 33, 97-102. [CrossRef]

41. Kramvis, A. Genotypes and Genetic Variability of Hepatitis B Virus. Intervirology 2014, 57, 141-150. [CrossRef]

42. McNaughton, A.L.; Revill, P.A.; Littlejohn, M.; Matthews, P.C.; Ansari, M.A. Analysis of genomic-length HBV sequences to determine genotype and subgenotype reference sequences. J. Gen. Virol. 2020. [CrossRef]

43. Yin, Y.; He, K.; Wu, B.; Xu, M.; Du, L.; Liu, W.; Liao, P.; Liu, Y.; He, M. A systematic genotype and subgenotype re-ranking of hepatitis B virus under a novel classification standard. Heliyon 2019, 5, e02556. [CrossRef] [PubMed]

44. Congly, S.E.; Wong, P.; Al-Busafi, S.A.; Doucette, K.; Fung, S.K.; Ghali, P.; Fonseca, K.; Myers, R.P.; Osiowy, C.; Coffin, C.S. Characterization of hepatitis B virus genotypes and quantitative hepatitis B surface antigen titres in North American tertiary referral liver centres. Liver Int. 2013, 33, 1363-1369. [CrossRef] [PubMed] 
45. Coffin, C.S.; Ramji, A.; Cooper, C.L.; Miles, D.; Doucette, K.E.; Wong, P.; Tam, E.; Wong, D.K.; Wong, A.; Ukabam, S.; et al. Epidemiologic and clinical features of chronic hepatitis B virus infection in 8 Canadian provinces: A descriptive study by the Canadian HBV Network. CMAJ Open 2019, 7, E610-E617. [CrossRef]

46. Zhang, X.; Zoulim, F.; Habersetzer, F.; Xiong, S.; Trépo, C. Analysis of hepatitis B virus genotypes and pre-core region variability during interferon treatment of HBe antigen negative chronic hepatitis B. J. Med. Virol. 1996, 48, 8-16. [CrossRef]

47. Erhardt, A.; Blondin, D.; Hauck, K.; Sagir, A.; Kohnle, T.; Heintges, T.; Häussinger, D. Response to interferon alfa is hepatitis B virus genotype dependent: Genotype A is more sensitive to interferon than genotype D. Gut 2005, 54, 1009-1013. [CrossRef] [PubMed]

48. Zhang, Y.; Wu, Y.; Ye, S.; Wang, T.; Zhao, R.; Chen, F.; Abe, K.; Jin, X. The response to interferon is influenced by hepatitis B virus genotype in vitro and in vivo. Virus Res. 2013, 171, 65-70. [CrossRef]

49. Wai, C. HBV genotype B is associated with better response to interferon therapy in $\mathrm{HBe} A g(+)$ chronic hepatitis than genotype C. Hepatology 2002, 36, 1425-1430. [CrossRef]

50. Kao, J.-H.; Chen, P.-J.; Lai, M.-Y.; Chen, P.-J. Hepatitis B genotypes correlate with clinical outcomes in patients with chronic hepatitis B. Gastroenterology 2000, 118, 554-559. [CrossRef]

51. Chen, C.-J.; Iloeje, U.H.; Yang, H.-I. Long-Term Outcomes in Hepatitis B: The REVEAL-HBV Study. Clin. Liver Dis. 2007, 11, 797-816. [CrossRef]

52. Yan, H.; Yang, Y.; Zhang, L.; Tang, G.; Wang, Y.; Xue, G.; Zhou, W.; Sun, S. Characterization of the genotype and integration patterns of hepatitis B virus in early- and late-onset hepatocellular carcinoma. Hepatology 2015, 61, 1821-1831. [CrossRef]

53. Yuan, J.; Zhou, B.; Tanaka, Y.; Kurbanov, F.; Orito, E.; Gong, Z.; Xu, L.; Lu, J.; Jiang, X.; Lai, W.; et al. Hepatitis $B$ virus (HBV) genotypes/subgenotypes in China: Mutations in core promoter and precore/core and their clinical implications. J. Clin. Virol. 2007, 39, 87-93. [CrossRef] [PubMed]

54. Coffin, C.S.; Osiowy, C.; Gao, S.; Nishikawa, S.; Van Der Meer, F.; Van Marle, G. Hepatitis B virus (HBV) variants fluctuate in paired plasma and peripheral blood mononuclear cells among patient cohorts during different chronic hepatitis B (CHB) disease phases. J. Viral Hepat. 2014, 22, 416-426. [CrossRef] [PubMed]

55. Gao, S.; Duan, Z.; Chen, Y.; Van Der Meer, F.; Lee, S.S.; Osiowy, C.; Van Marle, G.; Coffin, C.S. Compartmental HBV evolution and replication in liver and extrahepatic sites after nucleos/tide analogue therapy in chronic hepatitis B carriers. J. Clin. Virol. 2017, 94, 8-14. [CrossRef] [PubMed]

56. Coffin, C.S.; Mulrooney-Cousins, P.M.; Peters, M.G.; Van Marle, G.; Roberts, J.P.; Michalak, T.I.; Terrault, N.A. Molecular characterization of intrahepatic and extrahepatic hepatitis B virus (HBV) reservoirs in patients on suppressive antiviral therapy. J. Viral Hepat. 2011, 18, 415-423. [CrossRef]

57. Sonneveld, M.J.; Rijckborst, V.; Zeuzem, S.; Heathcote, E.J.; Simon, K.; Senturk, H.; Pas, S.D.; Hansen, B.E.; Janssen, H.L.A. Presence of precore and core promoter mutants limits the probability of response to peginterferon in hepatitis B e antigen-positive chronic hepatitis B. Hepatology 2012, 56, 67-75. [CrossRef]

58. Sonneveld, M.J.; Rijckborst, V.; Zwang, L.; Zeuzem, S.; Heathcote, E.J.; Simon, K.; Zoutendijk, R.; Akarca, U.; Pas, S.D.; Hansen, B.E.; et al. Hepatitis B e antigen levels and response to peginterferon: Influence of precore and basal core promoter mutants. Antivir. Res. 2013, 97, 312-317. [CrossRef]

59. Gao, S.; Duan, Z.-P.; Coffin, C.S. Clinical relevance of hepatitis B virus variants. World J. Hepatol. 2015, 7, 1086-1096. [CrossRef]

60. Zoulim, F.; Locarnini, S. Hepatitis B Virus Resistance to Nucleos(t)ide Analogues. Gastroenterology 2009, 137, 1593-1608. [CrossRef]

61. Liang, X.; Gao, Z.; Xie, Q.; Zhang, J.; Sheng, J.; Cheng, J.; Chen, C.; Mao, Q.; Zhao, W.; Ren, H.; et al. Long-term efficacy and safety of tenofovir disoproxil fumarate in Chinese patients with chronic hepatitis B: 5-year results. Hepatol. Int. 2019, 13, 260-269. [CrossRef]

62. Liu, Y.; Corsa, A.C.; Buti, M.; Cathcart, A.L.; Flaherty, J.F.; Miller, M.D.; Kitrinos, K.M.; Marcellin, P.; Gane, E.J. No detectable resistance to tenofovir disoproxil fumarate in $\mathrm{HBeAg}+$ and $\mathrm{HBeAg}-$ patients with chronic hepatitis B after 8 years of treatment. J. Viral Hepat. 2016, 24, 68-74. [CrossRef]

63. Kwon, J.H.; Song, M.J.; Jang, J.W.; Bae, S.H.; Choi, J.Y.; Yoon, S.K.; Kim, H.Y.; Kim, C.W.; Song, D.S.; Chang, U.I.; et al. Efficacy and Safety of Tenofovir Disoproxil Fumarate in Treatment-Naïve Patients with Chronic Hepatitis B in Korea. Dig. Dis. Sci. 2019, 64, 2039-2048. [CrossRef] [PubMed] 
64. Marcellin, P.; Wong, D.K.; Sievert, W.; Buggisch, P.; Petersen, J.; Flisiak, R.; Manns, M.; Kaita, K.; Krastev, Z.; Lee, S.S.; et al. Ten-year efficacy and safety of tenofovir disoproxil fumarate treatment for chronic hepatitis B virus infection. Liver Int. 2019, 39, 1868-1875. [CrossRef] [PubMed]

65. Cathcart, A.L.; Chan, H.L.-Y.; Bhardwaj, N.; Liu, Y.; Marcellin, P.; Pan, C.Q.; Shalimar; Buti, M.; Cox, S.; Parhy, B.; et al. No Resistance to Tenofovir Alafenamide Detected through 96 Weeks of Treatment in Patients with Chronic Hepatitis B Infection. Antimicrob. Agents Chemother. 2018, 62. [CrossRef] [PubMed]

66. Jiang, D.; Wang, J.; Zhao, X.; Li, Y.; Zhang, Q.; Song, C.; Zeng, H.; Wang, X. Entecavir resistance mutations rtL180M/T184L/M204V combined with rtA200V lead to tenofovir resistance. Liver Int. 2019. [CrossRef]

67. Park, E.-S.; Lee, A.R.; Kim, D.H.; Lee, J.-H.; Yoo, J.-J.; Ahn, S.H.; Sim, H.; Park, S.; Kang, H.S.; Won, J.; et al. Identification of a quadruple mutation that confers tenofovir resistance in chronic hepatitis B patients. J. Hepatol. 2019, 70, 1093-1102. [CrossRef]

68. Liu, S.; Zhang, H.; Gu, C.; Yin, J.; He, Y.; Xie, J.; Cao, G. Associations Between Hepatitis B Virus Mutations and the Risk of Hepatocellular Carcinoma: A Meta-Analysis. J. Natl. Cancer Inst. 2009, 101, 1066-1082. [CrossRef]

69. Chen, C.; Hung, C.; Chen, W.; Hu, T.; Wang, J.; Wang, J.; Lu, S.-N.; Changchien, C. Pre-S Deletion and Complex Mutations of Hepatitis B Virus Related to Advanced Liver Disease in HBeAg-Negative Patients. Gastroenterology 2007, 133, 1466-1474. [CrossRef]

70. Huang, S.-N.; Chisari, F.V. Strong, sustained hepatocellular proliferation precedes hepatocarcinogenesis in hepatitis B surface antigen transgenic mice. Hepatology 1995, 21, 620-626.

71. Pollicino, T.; Cacciola, I.; Saffioti, F.; Raimondo, G. Hepatitis B virus PreS/S gene variants: Pathobiology and clinical implications. J. Hepatol. 2014, 61, 408-417. [CrossRef]

72. Su, I.-J.; Wang, H.-C.; Wu, H.-C.; Huang, W.-Y. Ground glass hepatocytes contain pre-S mutants and represent preneoplastic lesions in chronic hepatitis B virus infection. J. Gastroenterol. Hepatol. 2008, 23, 1169-1174. [CrossRef]

73. Hadziyannis, S.; Gerber, M.A.; Vissoulis, C.; Popper, H. Cytoplasmic hepatitis B antigen in "ground-glass" hepatocytes of carriers. Arch. Pathol. 1973, 96, 327-330. [PubMed]

74. Wang, H.-C.; Huang, W.; Lai, M.-D.; Su, I.-J. Hepatitis B virus pre-S mutants, endoplasmic reticulum stress and hepatocarcinogenesis. Cancer Sci. 2006, 97, 683-688. [CrossRef] [PubMed]

75. Wang, Y.; Zeng, L.; Chen, W. HBV X gene point mutations are associated with the risk of hepatocellular carcinoma: A systematic review and meta-analysis. Mol. Clin. Oncol. 2016, 4, 1045-1051. [CrossRef] [PubMed]

76. Zhang, X.; Ding, H.-G. Key role of hepatitis B virus mutation in chronic hepatitis B development to hepatocellular carcinoma. World J. Hepatol. 2015, 7, 1282-1286. [CrossRef] [PubMed]

77. Park, Y.M.; Jang, J.W.; Yoo, S.H.; Kim, S.H.; Oh, I.M.; Park, S.J.; Jang, Y.S.; Lee, S.J. Combinations of eight key mutations in the $\mathrm{X} /$ preC region and genomic activity of hepatitis $\mathrm{B}$ virus are associated with hepatocellular carcinoma. J. Viral Hepat. 2013, 21, 171-177. [CrossRef] [PubMed]

78. Wen, J.; Song, C.; Jiang, D.; Jin, T.; Dai, J.; Zhu, L.; An, J.; Liu, Y.; Ma, S.; Qin, N.; et al. Hepatitis B virus genotype, mutations, human leukocyte antigen polymorphisms and their interactions in hepatocellular carcinoma: A multi-centre case-control study. Sci. Rep. 2015, 5, 16489. [CrossRef]

79. Yin, J.; Xie, J.; Liu, S.; Zhang, H.; Han, L.; Lu, W.; Shen, Q.; Xu, G.; Dong, H.; Shen, J.; et al. Association Between the Various Mutations in Viral Core Promoter Region to Different Stages of Hepatitis B, Ranging of Asymptomatic Carrier State to Hepatocellular Carcinoma. Am. J. Gastroenterol. 2011, 106, 81-92. [CrossRef]

80. Yu, L.; Zhang, B.-F.; Cheng, M.-L.; Zhao, X.-K.; Zhang, Q.; Hu, Y.-X.; Liu, H.-J.; Mu, M.; Wang, B.; Yang, G.-Z.; et al. Quantitative assessment of mutations in hepatitis B virus genome with liver cirrhosis and hepatocellular carcinoma development. Oncotarget 2016, 5. [CrossRef]

81. Yan, J.; Yao, Z.; Hu, K.; Zhong, Y.; Li, M.; Xiong, Z.; Deng, M. Hepatitis B Virus Core Promoter A1762T/G1764A (TA)/T1753A/T1768A Mutations Contribute to Hepatocarcinogenesis by Deregulating Skp2 and P53. Dig. Dis. Sci. 2015, 60, 1315-1324. [CrossRef]

82. Carman, W.; Hadziyannis, S.; McGarvey, M.J.; Jacyna, M.; Karayiannis, P.; Makris, A.; Thomas, H. Mutation Preventing Formation of Hepatitis B E Antigen in Patients with Chronic Hepatitis B Infection. Lancet 1989, 334, 588-591. [CrossRef]

83. Jammeh, S.; Tavner, F.; Watson, R.; Thomas, H.C.; Karayiannis, P. Effect of basal core promoter and pre-core mutations on hepatitis B virus replication. J. Gen. Virol. 2008, 89, 901-909. [CrossRef] [PubMed] 
84. Ferns, R.B.; Naoumov, N.V.; Gilson, R.J.; Tedder, R.S. Presence of hepatitis B virus core promoter mutations pre-seroconversion predict persistent viral replication after HBeAg loss. J. Clin. Virol. 2007, 39, $199-204$. [CrossRef] [PubMed]

85. Peng, X.M.; Huang, G.-M.; Li, J.-G.; Huang, Y.-S.; Mei, Y.-Y.; Gao, Z.-L. High level of hepatitis B virus DNA after HBeAg-to-anti-HBe seroconversion is related to coexistence of mutations in its precore and basal core promoter. World J. Gastroenterol. 2005, 11, 3131-3134. [CrossRef]

86. Tu, T.; Budzinska, M.A.; Shackel, N.A.; Urban, S. HBV DNA Integration: Molecular Mechanisms and Clinical Implications. Viruses 2017, 9, 75. [CrossRef]

87. Yang, W.; Summers, J. Illegitimate replication of linear hepadnavirus DNA through nonhomologous recombination. J. Virol. 1995, 69, 4029-4036. [CrossRef] [PubMed]

88. Bill, C.A.; Summers, J. Genomic DNA double-strand breaks are targets for hepadnaviral DNA integration. Proc. Natl. Acad. Sci. USA 2004, 101, 11135-11140. [CrossRef]

89. Zhao, L.-H.; Liu, X.; Yan, H.-X.; Li, W.-Y.; Zeng, X.; Yang, Y.; Zhao, J.; Liu, S.-P.; Zhuang, X.-H.; Lin, C.; et al. Genomic and oncogenic preference of HBV integration in hepatocellular carcinoma. Nat. Commun. 2016, 7, 12992. [CrossRef]

90. Ruan, P.; Dai, X.; Sun, J.; He, C.; Huang, C.; Zhou, R.; Cao, Z.; Ye, L. Different types of viral-host junction found in HBV integration breakpoints in HBV-infected patients. Mol. Med. Rep. 2018, 19, 1410-1416. [CrossRef]

91. Tu, T.; Budzinska, M.A.; Vondran, F.W.R.; Shackel, N.A.; Urban, S. Hepatitis B virus DNA integration occurs early in the viral life cycle in an in vitro infection model via NTCP-dependent uptake of enveloped virus particles. J. Virol. 2018, 92, e02007-17. [CrossRef]

92. Tu, T.; Mason, W.S.; Clouston, A.; Shackel, N.A.; McCaughan, G.W.; Yeh, M.M.; Schiff, E.R.; Ruszkiewicz, A.R.; Chen, J.W.; Harley, H.A.J.; et al. Clonal expansion of hepatocytes with a selective advantage occurs during all stages of chronic hepatitis B virus infection. J. Viral Hepat. 2015, 22, 737-753. [CrossRef]

93. Mason, W.S.; Gill, U.S.; Litwin, S.; Zhou, Y.; Peri, S.; Pop, O.; Hong, M.L.; Naik, S.; Quaglia, A.; Bertoletti, A.; et al. HBV DNA Integration and Clonal Hepatocyte Expansion in Chronic Hepatitis B Patients Considered Immune Tolerant. Gastroenterology 2016, 151, 986-998. [CrossRef] [PubMed]

94. Chauhan, R.; Churchill, N.D.; Mulrooney-Cousins, P.M.; Michalak, T.I. Initial sites of hepadnavirus integration into host genome in human hepatocytes and in the woodchuck model of hepatitis B-associated hepatocellular carcinoma. Oncogenesis 2017, 6, e317. [CrossRef] [PubMed]

95. Furuta, M.; Tanaka, H.; Shiraishi, Y.; Unida, T.; Imamura, M.; Fujimoto, A.; Fujita, M.; Sasaki, A.-O.; Maejima, K.; Nakano, K.; et al. Characterization of HBV integration patterns and timing in liver cancer and HBV-infected livers. Oncotarget 2018, 9, 25075-25088. [CrossRef] [PubMed]

96. Sung, W.-K.; Zheng, H.; Li, S.; Chen, R.; Liu, X.; Li, Y.; Lee, N.P.; Lee, W.H.; Ariyaratne, P.N.; Tennakoon, C.; et al. Genome-wide survey of recurrent HBV integration in hepatocellular carcinoma. Nat. Genet. 2012, 44, 765-769. [CrossRef] [PubMed]

97. Budzinska, M.A.; Shackel, N.A.; Urban, S.; Tu, T. Cellular Genomic Sites of Hepatitis B Virus DNA Integration. Genes 2018, 9, 365. [CrossRef]

98. Tu, T.; Budzinska, M.A.; Shackel, N.A.; Jilbert, A.R. Conceptual models for the initiation of hepatitis B virus-associated hepatocellular carcinoma. Liver Int. 2015, 35, 1786-1800. [CrossRef]

99. Paterlini-Brechot, P.; Saigo, K.; Murakami, Y.; Chami, M.; Gozuacik, D.; Mugnier, C.; Lagorce, D.; Brechot, C.; Paterlini-Br, P. Eacute, Hepatitis B virus-related insertional mutagenesis occurs frequently in human liver cancers and recurrently targets human telomerase gene. Oncogene 2003, 22, 3911-3916. [CrossRef]

100. Ferber, M.J.; Montoya, D.P.; Yu, C.; Aderca, I.; McGee, A.; Thorland, E.C.; Nagorney, D.M.; Gostout, B.S.; Burgart, L.J.; Boix, L.; et al. Integrations of the hepatitis B virus (HBV) and human papillomavirus (HPV) into the human telomerase reverse transcriptase (hTERT) gene in liver and cervical cancers. Oncogene 2003, 22, 3813-3820. [CrossRef]

101. Gozuacik, D.; Murakami, Y.; Saigo, K.; Chami, M.; Mugnier, C.; Lagorce, D.; Okanoue, T.; Urashima, T.; Brechot, C.; Paterlini-Brechot, P. Identification of human cancer-related genes by naturally occurring Hepatitis B Virus DNA tagging. Oncogene 2001, 20, 6233-6240. [CrossRef]

102. Toh, S.T.; Jin, Y.; Liu, L.; Wang, J.; Babrzadeh, F.; Gharizadeh, B.; Ronaghi, M.; Toh, H.C.; Chow, P.K.; Chung, A.Y.-F.; et al. Deep sequencing of the hepatitis B virus in hepatocellular carcinoma patients reveals enriched integration events, structural alterations and sequence variations. Carcinogenesis 2012, 34, 787-798. [CrossRef] 
103. Li, W.; Zeng, X.; Lee, N.P.; Liu, X.; Chen, S.; Guo, B.; Yi, S.; Zhuang, X.; Chen, F.; Wang, G.; et al. HIVID: An efficient method to detect HBV integration using low coverage sequencing. Genomics 2013, 102, 338-344. [CrossRef] [PubMed]

104. Nault, J.-C.; Calderaro, J.; Di Tommaso, L.; Balabaud, C.; Zafrani, E.S.; Bioulac-Sage, P.; Roncalli, M.; Zucman-Rossi, J. Telomerase reverse transcriptase promoter mutation is an early somatic genetic alteration in the transformation of premalignant nodules in hepatocellular carcinoma on cirrhosis. Hepatology 2014, 60, 1983-1992. [CrossRef] [PubMed]

105. Nault, J.C.; Mallet, M.; Pilati, C.; Calderaro, J.; Bioulac-Sage, P.; Laurent, C.; Laurent, A.; Cherqui, D.; Balabaud, C.; Zucman, J.-R. High frequency of telomerase reverse-transcriptase promoter somatic mutations in hepatocellular carcinoma and preneoplastic lesions. Nat. Commun. 2013, 4, 2218. [CrossRef] [PubMed]

106. Murakami, Y.; Saigo, K.; Takashima, H.; Minami, M.; Okanoue, T.; Bréchot, C.; Paterlini-Brechot, P. Large scaled analysis of hepatitis B virus (HBV) DNA integration in HBV related hepatocellular carcinomas. Gut 2005, 54, 1162-1168. [CrossRef]

107. Dong, H.; Zhang, L.; Qian, Z.; Zhu, X.; Zhu, G.; Chen, Y.; Xie, X.; Ye, Q.; Zang, J.; Ren, Z.-G.; et al. Identification of HBV-MLL4 Integration and Its Molecular Basis in Chinese Hepatocellular Carcinoma. PLoS ONE 2015, 10, e0123175. [CrossRef]

108. Anastasiadou, E.; Jacob, L.S.; Slack, F.J. Non-coding RNA networks in cancer. Nat. Rev. Cancer 2017, 18, 5-18. [CrossRef]

109. Lim, L.J.; Wong, S.Y.; Huang, F.; Lim, S.; Chong, S.S.; Ooi, L.L.; Kon, O.L.; Lee, C.G.L. Roles and Regulation of Long Noncoding RNAs in Hepatocellular Carcinoma. Cancer Res. 2019, 79, 5131-5139. [CrossRef]

110. Lau, C.-C.; Sun, T.; Ching, A.K.; He, M.; Li, J.W.; Wong, A.M.; Na Co, N.; Chan, A.W.; Li, P.-S.; Lung, R.W.; et al. Viral-Human Chimeric Transcript Predisposes Risk to Liver Cancer Development and Progression. Cancer Cell 2014, 25, 335-349. [CrossRef]

111. Michalak, T.I.; Mulrooney, P.M.; Coffin, C.S. Low doses of hepadnavirus induce infection of the lymphatic system that does not engage the liver. J. Virol. 2004, 78, 1730-1738. [CrossRef]

112. Lew, Y.-Y.; Michalak, T.I. In Vitro and In Vivo Infectivity and Pathogenicity of the Lymphoid Cell-Derived Woodchuck Hepatitis Virus. J. Virol. 2001, 75. [CrossRef]

113. Mulrooney-Cousins, P.M.; Michalak, T.I. Repeated Passage of Wild-Type Woodchuck Hepatitis Virus in Lymphoid Cells Does Not Generate Cell Type-Specific Variants or Alter Virus Infectivity. J. Virol. 2008, 82, 7540-7550. [CrossRef] [PubMed]

114. Korba, B.E.; Cote, P.J.; Gerin, J.L. Mitogen-induced replication of woodchuck hepatitis virus in cultured peripheral blood lymphocytes. Science 1988, 241, 1213-1216. [CrossRef] [PubMed]

115. Coffin, C.S.; Mulrooney-Cousins, P.M.; Van Marle, G.; Roberts, J.P.; Michalak, T.I.; Terrault, N. Hepatitis B virus quasispecies in hepatic and extrahepatic viral reservoirs in liver transplant recipients on prophylactic therapy. Liver Transplant. 2011, 17, 955-962. [CrossRef] [PubMed]

116. Murakami, Y.; Minami, M.; Daimon, Y.; Okanoue, T. Hepatitis B virus DNA in liver, serum, and peripheral blood mononuclear cells after the clearance of serum hepatitis B virus surface antigen. J. Med Virol. 2003, 72, 203-214. [CrossRef] [PubMed]

117. Brind, A.; Jiang, J.; Samuel, D.; Gigou, M.; Féray, C.; Bréchot, C.; Kremsdorf, D. Evidence for selection of hepatitis B mutants after liver transplantation through peripheral blood mononuclear cell infection. J. Hepatol. 1997, 26, 228-235. [CrossRef]

118. Torii, N. Configuration and replication competence of hepatitis B virus DNA in peripheral blood mononuclear cells from chronic hepatitis B patients and patients who have recovered from acute self-limited hepatitis. Hepatol. Res. 2003, 25, 234-243. [CrossRef]

119. Mason, A.L.; Wick, M.; White, H.; Perrillo, R. Hepatitis B virus replication in diverse cell types during chronic hepatitis B virus infection. Hepatology 1993, 18, 781-789. [CrossRef]

120. Yoffe, B.; Burns, D.K.; Bhatt, H.S.; Combes, B. Extrahepatic hepatitis B virus DNA sequences in patients with acute hepatitis B infection. Hepatology 1990, 12, 187-192. [CrossRef]

121. Lu, L.; Zhang, H.-Y.; Yueng, Y.-H.; Cheung, K.-F.; Luk, J.M.; Wang, F.-S.; Lau, G.K.-K. Intracellular levels of hepatitis B virus DNA and pregenomic RNA in peripheral blood mononuclear cells of chronically infected patients. J. Viral Hepat. 2009, 16, 104-112. [CrossRef] 
122. Lee, Z.; Nishikawa, S.; Gao, S.; Eksteen, J.B.; Czub, M.; Gill, M.J.; Osiowy, C.; Van Der Meer, F.; Van Marle, G.; Coffin, C.S. Detection of Hepatitis B Virus (HBV) Genomes and HBV Drug Resistant Variants by Deep Sequencing Analysis of HBV Genomes in Immune Cell Subsets of HBV Mono-Infected and/or Human Immunodeficiency Virus Type-1 (HIV-1) and HBV Co-Infected Individuals. PLoS ONE 2015, 10, e0137568. [CrossRef]

123. Trippler, M.; Büschenfelde, K.-H.M.Z.; Gerken, G. HBV viral load within subpopulations of peripheral blood mononuclear cells in HBV infection using limiting dilution PCR. J. Virol. Methods 1999, 78, 129-147. [CrossRef]

124. Chemin, I.; Vermot-Desroches, C.; Baginski, I.; Saurin, J.C.; Laurent, F.; Zoulim, F.; Bernaud, J.; Lamelin, J.P.; Hantz, O.; Rigal, D.; et al. Selective detection of human hepatitis B virus surface and core antigens in peripheral blood mononuclear cell subsets by flow cytometry. J. Viral Hepat. 1994, 1, 39-44. [CrossRef] [PubMed]

125. Yan, Q.; Lan, Y.; Huang, Y.; Fan, R.; Liu, L.; Song, S.; Li, Y. Hepatitis B virus replication is upregulated in proliferated peripheral blood lymphocytes. Mol. Med. Rep. 2016, 13, 3581-3587. [CrossRef] [PubMed]

126. Huang, Y.; Yan, Q.; Fan, R.; Song, S.; Ren, H.; Li, Y.; Lan, Y. Hepatitis B Virus Replication in CD34+ Hematopoietic Stem Cells from Umbilical Cord Blood. Med. Sci. Monit. 2016, 22, 1673-1681. [CrossRef]

127. Lau, K.C.; Joshi, S.S.; Gao, S.; Giles, E.; Swidinsky, K.; Van Marle, G.; Bathe, O.F.; Urbanski, S.J.; Terrault, N.A.; Burak, K.W.; et al. Oncogenic HBV variants and integration are present in hepatic and lymphoid cells derived from chronic HBV patients. Cancer Lett. 2020, 480, 39-47. [CrossRef]

128. Bouffard, P.; Lamelin, J.-P.; Zoulim, F.; Lepot, D.; Trepo, C. Phytohemagglutinin and concanavalin A activate hepatitis B virus in peripheral blood mononuclear cells of patients with chronic hepatitis B virus infection. J. Med. Virol. 1992, 37, 255-262. [CrossRef]

129. Zhou, X.; Pan, H.; Yang, P.; Ye, P.; Cao, H.; Zhou, H. Both chronic HBV infection and naturally acquired HBV immunity confer increased risks of B-cell non-Hodgkin lymphoma. BMC Cancer 2019, 19, 477. [CrossRef]

130. Zhao, X.; Guo, X.; Xing, L.; Yue, W.; Yin, H.; He, M.; Wang, J.; Yang, J.; Chen, J. HBV infection potentiates resistance to S-phase arrest-inducing chemotherapeutics by inhibiting CHK2 pathway in diffuse large B-cell lymphoma. Cell Death Dis. 2018, 9, 61. [CrossRef]

131. Deng, L.; Song, Y.; Young, K.H.; Hu, S.; Ding, N.; Song, W.; Li, X.; Shi, Y.; Huang, H.; Liu, W.; et al. Hepatitis $B$ virus-associated diffuse large B-cell lymphoma: Unique clinical features, poor outcome, and hepatitis B surface antigen-driven origin. Oncotarget 2015, 6, 25061-25073. [CrossRef]

132. Engels, E.A.; Cho, E.R.; Jee, S.H. Hepatitis B virus infection and risk of non-Hodgkin lymphoma in South Korea: A cohort study. Lancet Oncol. 2010, 11, 827-834. [CrossRef]

133. Li, M.; Gan, Y.; Fan, C.; Yuan, H.; Zhang, X.; Shen, Y.; Wang, Q.; Meng, Z.; Xu, D.; Tu, H. Hepatitis B virus and risk of non-Hodgkin lymphoma: An updated meta-analysis of 58 studies. J. Viral Hepat. 2018, 25, 894-903. [CrossRef]

134. Su, T.-H.; Liu, C.-J.; Tseng, T.-C.; Chou, S.-W.; Liu, C.-H.; Yang, H.-C.; Wu, S.-J.; Chen, P.-J.; Chen, D.-S.; Chen, C.-L.; et al. Chronic hepatitis B is associated with an increased risk of B-cell non-Hodgkin's lymphoma and multiple myeloma. Aliment. Pharmacol. Ther. 2019, 49, 589-598. [CrossRef] [PubMed]

135. Sinha, M.; Rao, C.R.; Premalata, C.S.; Shafiulla, M.; Lakshmaiah, K.C.; Jacob, L.A.; Babu, G.K.; Viveka, B.K.; Appaji, L.; Subramanyam, J.R. Plasma Epstein-Barr virus and Hepatitis B virus in non-Hodgkin lymphomas: Two lymphotropic, potentially oncogenic, latently occurring DNA viruses. Indian J. Med. Paediatr. Oncol. 2016, 37, 146-151. [CrossRef]

136. Dalia, S.; Chavez, J.; Castillo, J.J.; Sokol, L. Hepatitis B infection increases the risk of non-Hodgkin lymphoma: A meta-analysis of observational studies. Leuk. Res. 2013, 37, 1107-1115. [CrossRef] [PubMed]

137. Wang, Y.; Wang, H.; Pan, S.; Hu, T.; Shen, J.; Zheng, H.; Xie, S.; Xie, Y.; Renquan, L.; Guo, L. Capable Infection of Hepatitis B Virus in Diffuse Large B-cell Lymphoma. J. Cancer 2018, 9, 1575-1581. [CrossRef] [PubMed]

138. Shi, Y.; Lan, Y.; Cao, F.; Teng, Y.; Li, L.; Wang, F.; Li, J.; Zhou, J.; Li, Y. Infected hematopoietic stem cells and with integrated HBV DNA generate defective T cells in chronic HBV infection patients. J. Viral Hepat. 2014, 21, e39-e47. [CrossRef] [PubMed]

139. Saitta, C.; Tripodi, G.; Barbera, A.; Bertuccio, A.; Smedile, A.; Ciancio, A.; Raffa, G.; SanGiovanni, A.; Navarra, G.; Raimondo, G.; et al. Hepatitis B virus (HBV) DNA integration in patients with occult HBV infection and hepatocellular carcinoma. Liver Int. 2015, 35, 2311-2317. [CrossRef] 
140. Sinha, M.; Sundar, K.; Premalata, C.S.; Asati, V.; Murali, A.; Bajpai, A.K.; Davuluri, S.; Acharya, K.K.; Lakshmaiah, K.C.; Babu, G.K.; et al. Pro-oncogenic, intra host viral quasispecies in Diffuse large B cell lymphoma patients with occult Hepatitis B Virus infection. Sci. Rep. 2019, 9, 14516-14518. [CrossRef]

141. Nikitina, E.; Larionova, I.; Choinzonov, E.L.; Kzhyshkowska, J. Monocytes and Macrophages as Viral Targets and Reservoirs. Int. J. Mol. Sci. 2018, 19, 2821. [CrossRef]

142. Oropeza, C.E.; Tarnow, G.; Sridhar, A.; Taha, T.Y.; Shalaby, R.E.; McLachlan, A. The Regulation of HBV Transcription and Replication. Adv. Exp. Med. Biol. 2020, 1179, 39-69. [CrossRef]

143. Jin, Y.-M.; Churchill, N.D.; Michalak, T.I. Protease-activated lymphoid cell and hepatocyte recognition site in the preS1 domain of the large woodchuck hepatitis virus envelope protein. J. Gen. Virol. 1996, 77, 1837-1846. [CrossRef] [PubMed]

144. Fanning, G.C.; Zoulim, F.; Hou, J.; Bertoletti, A. Therapeutic strategies for hepatitis B virus infection: Towards a cure. Nat. Rev. Drug Discov. 2019, 18, 827-844. [CrossRef] [PubMed]

145. Yip, T.C.; Lok, A.S.-F. How Do We Determine Whether a Functional Cure for HBV Infection Has Been Achieved? Clin. Gastroenterol. Hepatol. 2020, 18, 548-550. [CrossRef] [PubMed]

146. Raimondo, G.; Allain, J.-P.; Brunetto, M.R.; Buendia, M.A.; Chen, P.-J.; Colombo, M.; Craxi, A.; Donato, F.; Ferrari, C.; Gaeta, G.B.; et al. Statements from the Taormina expert meeting on occult hepatitis B virus infection. J. Hepatol. 2008, 49, 652-657. [CrossRef]

147. Raimondo, G.; Caccamo, G.; Filomia, R.; Pollicino, T. Occult HBV infection. Semin. Immunopathol. 2012, 35, 39-52. [CrossRef]

148. Yip, T.C.-F.; Wong, G.L. Current Knowledge of Occult Hepatitis B Infection and Clinical Implications. Semin. Liver Dis. 2019, 39, 249-260. [CrossRef]

149. Raimondo, G.; Locarnini, S.; Pollicino, T.; Levrero, M.; Zoulim, F.; Lok, A.S.; Taormina Workshop on Occult HBV Infection Faculty Members. Update of the statements on biology and clinical impact of occult hepatitis B virus infection. J. Hepatol. 2019, 71, 397-408. [CrossRef]

150. Mak, L.-Y.; Wong, D.K.-H.; Pollicino, T.; Raimondo, G.; Hollinger, F.B.; Yuen, M.-F. Occult hepatitis B infection and hepatocellular carcinoma: Epidemiology, virology, hepatocarcinogenesis and clinical significance. J. Hepatol. 2020, 73, 952-964. [CrossRef]

151. Simonetti, J.; Bulkow, L.; McMahon, B.J.; Homan, C.; Snowball, M.; Negus, S.; Williams, J.; Livingston, S.E. Clearance of hepatitis B surface antigen and risk of hepatocellular carcinoma in a cohort chronically infected with hepatitis B virus. Hepatology 2009, 51, 1531-1537. [CrossRef]

152. Ikeda, K.; Kobayashi, M.; Someya, T.; Saitoh, S.; Hosaka, T.; Akuta, N.; Suzuki, F.; Suzuki, Y.; Arase, Y.; Kumada, H. Occult hepatitis B virus infection increases hepatocellular carcinogenesis by eight times in patients with non-B, non-C liver cirrhosis: A cohort study. J. Viral Hepat. 2009, 16, 437-443. [CrossRef]

153. Shi, Y.; Wu, Y.H.; Wu, W.; Zhang, W.J.; Yang, J.; Chen, Z. Association between occult hepatitis B infection and the risk of hepatocellular carcinoma: A meta-analysis. Liver Int. 2011, 32, 231-240. [CrossRef] [PubMed]

154. Coppola, N.; Onorato, L.; Iodice, V.; Starace, M.; Minichini, C.; Farella, N.; Liorre, G.; Filippini, P.; Sagnelli, E.; De Stefano, G. Occult HBV infection in HCC and cirrhotic tissue of HBsAg-negative patients: A virological and clinical study. Oncotarget 2016, 7, 62706-62714. [CrossRef] [PubMed]

155. Wong, D.K.H.; Huang, F.Y.; Lai, C.-L.; Poon, R.T.P.; Seto, W.; Fung, J.; Hung, I.F.-N.; Yuen, M.-F. Occult hepatitis B infection and HBV replicative activity in patients with cryptogenic cause of hepatocellular carcinoma. Hepatology 2011, 54, 829-836. [CrossRef]

156. Muto, J.; Sugiyama, M.; Shirabe, K.; Mukaide, M.; Kirikae-Muto, I.; Ikegami, T.; Yoshizumi, T.; Yamashita, Y.-I.; Maehara, Y.; Mizokami, M. Frequency and Characteristics of Occult Hepatitis B Infection Among Hepatocellular Carcinoma Patients in Japan. Ann. Hepatol. 2018, 17, 596-603. [CrossRef] [PubMed]

157. Wong, D.K.-H.; Cheng, S.C.Y.; Mak, L.L.-Y.; To, E.W.-P.; Lo, R.C.-L.; Cheung, T.-T.; Seto, W.-K.; Fung, J.; Man, K.; Lai, C.-L.; et al. Among Patients with Undetectable Hepatitis B Surface Antigen and Hepatocellular Carcinoma, a High Proportion Has Integration of HBV DNA into Hepatocyte DNA and No Cirrhosis. Clin. Gastroenterol. Hepatol. 2020, 18, 449-456. [CrossRef] [PubMed]

158. Chen, X.-P.; Long, X.; Jia, W.-L.; Wu, H.-J.; Zhao, J.; Liang, H.-F.; Laurence, A.; Zhu, J.; Dong, D.; Chen, Y.; et al. Viral integration drives multifocal HCC during the occult HBV infection. J. Exp. Clin. Cancer Res. 2019, 38, 261. [CrossRef] 
159. Tajima, K.; Takahashi, N.; Ishizawa, K.; Murai, K.; Akagi, T.; Noji, H.; Sasaki, O.; Wano, M.; Itoh, J.; Kato, Y.; et al. High prevalence of diffuse large B-cell lymphoma in occult hepatitis B virus-infected patients in the Tohoku district in Eastern Japan. J. Med. Virol. 2016, 88, 2206-2210. [CrossRef]

160. Zhang, Z.; Zhang, Y.; Xu, N.; Huang, C.; Li, X.; Li, J. High risk of occult hepatitis B virus infection in leukemia patients from China. Arch. Virol. 2016, 162, 349-357. [CrossRef]

161. Chen, M.-H.; Hsiao, L.-T.; Chiou, T.-J.; Liu, J.-H.; Gau, J.-P.; Teng, H.-W.; Wang, W.-S.; Chao, T.-C.; Yen, C.-C.; Chen, P.-M. High prevalence of occult hepatitis B virus infection in patients with B cell non-Hodgkin's lymphoma. Ann. Hematol. 2008, 87, 475-480. [CrossRef]

162. Yeo, W.; Chan, T.C.; Leung, N.; Lam, W.Y.; Mo, F.K.; Chu, M.T.; Chan, H.L.; Hui, E.P.; Lei, K.I.; Mok, T.S.-K.; et al. Hepatitis B Virus Reactivation in Lymphoma Patients With Prior Resolved Hepatitis B Undergoing Anticancer Therapy With or Without Rituximab. J. Clin. Oncol. 2009, 27, 605-611. [CrossRef]

163. Kusumoto, S.; Tanaka, Y.; Ueda, R.; Mizokami, M. Reactivation of hepatitis B virus following rituximab-plus-steroid combination chemotherapy. J. Gastroenterol. 2010, 46, 9-16. [CrossRef] [PubMed]

164. Seto, W.; Chan, T.S.; Hwang, Y.-Y.; Wong, D.K.-H.; Fung, J.; Liu, K.S.-H.; Gill, H.; Lam, Y.-F.; Lie, A.K.; Lai, C.-L.; et al. Hepatitis B Reactivation in Patients With Previous Hepatitis B Virus Exposure Undergoing Rituximab-Containing Chemotherapy for Lymphoma: A Prospective Study. J. Clin. Oncol. 2014, 32, 3736-3743. [CrossRef] [PubMed]

165. Allweiss, L.; Dandri, M. Experimental in vitro and in vivo models for the study of human hepatitis B virus infection. J. Hepatol. 2016, 64, S17-S31. [CrossRef] [PubMed]

(C) 2020 by the authors. Licensee MDPI, Basel, Switzerland. This article is an open access article distributed under the terms and conditions of the Creative Commons Attribution (CC BY) license (http://creativecommons.org/licenses/by/4.0/). 